\title{
The Steady Man: Process and Policy in the Courts of the Roman Curiat
}

\author{
John T. Noonan, Jr.*
}

The two marriages of Charles, Duke of Lorraine, led to one of the most fascinating canonical trials of the seventeenth century. Professor Noonan uses this trial and its attendant circumstances as a springboard from which to examine the policies, procedures, and politics of post-Renaissance Roman Catholic law. His Article underlines the problems faced by a legal system that attempts to regulate the relationship between man and woman. In broader perspective, it analyzes the reaction of a legal system forced to compromise between abstract social values and practical necessity. Professor Noonan's analytical framework can be profitably utilized as a tool to examine the manner in which our current social policies are implemented and administered.

Anthropology rightly devotes great effort to deciphering the primitive attempts of inen to make law in the primordial patterns, for from this effort will coine material to illuminate our own behavior. But just as child psychology does not exhaust the study of man, so there is need to understand critically the functions of law in a more sophisticated phase. In its developed uses we are inore likely to see analogues to our present problems, more likely to gain insights into the purposes, perversions, characteristics, and limits of the legal way of ordering human behavior in a mature society. Especially is this true of a system far enough removed from our own to be looked at from a distance but close enough in its assumption and its methods so that comprehension is not strained. The canon law of marriage, parent of the American law of domestic relations, is such a system. Now the oldest as well as the inost widespread legal system alive in the conteinporary world, it was at its prime in the seventeenth century. This Article examines its function $\mathrm{m}$ a concrete case decided in $1653 .^{1}$

$\dagger$ This Article is adapted from the author's forthcoming book, SQUARES INTO Circles: Process and Policy in the Papal Dissolution of Marriage [@ 1970, John T. Noonan, Jr.], to be published later this year by the Harvard Press.

* Professor of Law, University of California, Berkeley. B.A. 1947, LL.B. 1954, Harvard University; Ph.D. 1951, Cathohic University.

1. Toul, January 15,1653,11 Decisionum recentiorum 396 (1716). For an explaination of rotal citations see notes 103-06 infra and accompanyimg text. 
By the system I mean the application of rules by those in cliarge, a series of interactions of persons mediated by a set of doctrines and shaped by the positions leld by the interacting persons within the organization. Classic canon law consisted of rules, and the study of these rules constituted the study of canon law. Without grasping the process by which the rules affect liuman beings, however, the significance of the law cannot be grasped. In the process of interaction the rules become incorporated in the acts of persons and lave impact upon the lives of persons. To understand the law is to understand its effect on those who actively or passively participate in the process.

In the seventeenth century canomical system, one may observe a bureaucracy in action and values in play in ways that cannot but suggest analogues to our own experience.

In a way not to be found in Anglo-American common law history before the nineteenth century, the briefs filed by the lawyers, and still preserved in the records of the court, offer the lawyers' own account of the case, their own view of the variables in the system. Observing these lawyers of 300 years ago one may see perhaps more sharply the advantages and disadvantages of a law supporting the demands of love and determining its symbol.

\section{I}

THE SPOUSE OF TWO

Charles was the grandson of the "great Henri," Duke of Lorraine. ${ }^{2}$ His father, François, prince of Vaudémont, was Henri I's second son. His mother, Christine de Salm, was the daughter of neighbouring nobility. One of nine children, Charles was his parents' oldest surviving son. Originally destined by them to hold the place of the House of

2. On the life of Charles, see Bonnard, Les Relations de la famille ducale de Lorraine in 70 \& 71 SOCIETE D'ARCHEOLOGIE LORRAINE, MEMOIRES (1932 \& 1933) [hereinafter cited as Societe]; 1 \& 3 A. Calmet, Historre ecclesiastique et civinLe DE LoRRaINe (1782); 1 F. DES RoBert, CAMPAGNES DE ChARLES IV v-Xii, $4-7$ (1883).

The following chart inay assist in identifying the principal characters:

Henri I

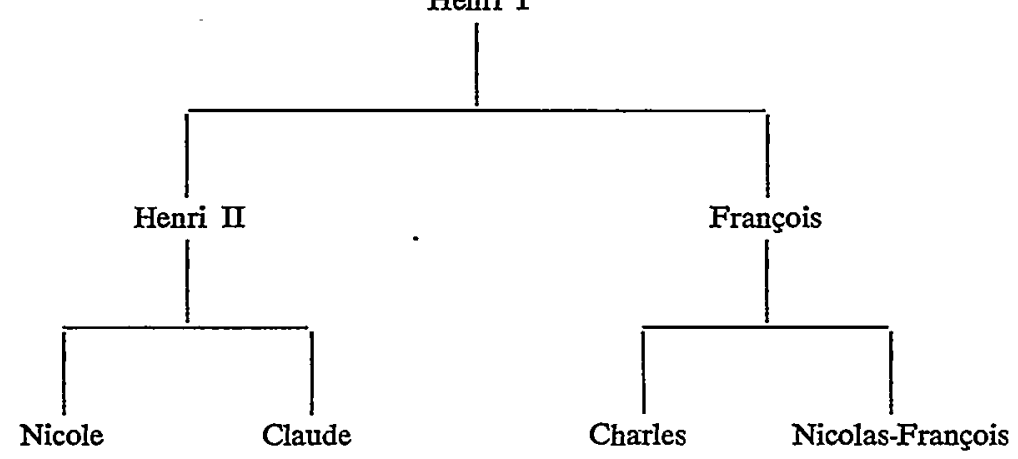


Lorraine in ecclesiastical life, this destiny was changed by the death of his older brother. He was now to succeed his father and to produce an heir.

At ten Charles was sent to Paris for schooling at the French court. At fourteen he was sent to study under the Jesuits at the University of Pont-à-Mousson-a university of 2,000 students founded by Charles' grandfather, the Duke, and his great-uncles, the Cardinal of Lorraine and the Cardinal of Guise and agreeably situated on the Moselle. Pontà-Mousson, the locus for the dissemination of Tridentine Cathohisism ${ }^{8}$ to the educated Catholics of Lorraine, made not imsignificant contributions to Charles' life beyond his two years of schooling there.

At sixteen he was sent to accompany his father, commanding general of the Catholic League, in the war against the Protestants. He had a year of service in Gerniany, but was kept out of the League's glorious victory, the Battle of Prague. Having been born April 5, 1604, lie was seventeen in 1621, when the story proper begins.

Charles was fair-lieaded and handsonie and charming to women. $\mathrm{He}$ was to be a bold and resourceful military commander. Sometimes generous and always nonclialant, lie was also unchaste, imprudent, and quarrelsome.

In 1621 he did not know Béatrice but he could not help knowing his young cousin Nicole. Nicole was the oldest daughter of Henri II, reigning Duke of Lorraine, son of the "great Henri" and older brother of Charles' father. On her mother's side she was the great granddaughter of a queen of France, Marie de Medici; the granddaughter of the Duke of Mantua; and the daughter of Marguerite de Gonzague.

When Nicole was very young, Henri IV of France had thought her the right mate for his son, Charles' classmate at Paris, the future Louis XIII. When French politics made a Spanish match more desirable for a French inonarch, Nicole was dropped. Her father then chose for her a good connection and a stalwart soldier, Louis de Guise, Baron d'Ancerville, a son born out of wedlock to the Cardinal de Guise-illegitimate, but still a member of the great family of Lorraine. Louis and Nicole were betrothed, though as the betrothal was made below the canonical age for marriage, it was not bimding on Nicole until she reached the age of consent, twelve, and ratified the contract. Born October 3,1608, in the spring of 1621 she had become just old enough to marry.

Nicole was well-forined but not beautiful. She was pious, goodhearted, and stubborn. ${ }^{4}$ If, at the age of twelve, she had affection for

3. That is, Catholicism as expounded by the Council of Trent.

4. 3 A. CALMET, supra note 2 , col. 543. 
any man, it was directed at the mature soldier her parents had chosen for her. ${ }^{5}$

Charles knew Nicole as he might be expected to know a cousin five years his junior. When she was a woman in her thirties, Charles could declare graciously that she had the inost beautiful arms he had ever seen, ${ }^{6}$ but there is no record that he was drawn by any part of her anatoiny when she was twelve, and her attainments at this age could hardly have attracted a young soldier and courtier. At the time it was settled that he should nrarry her, Charles was with the army in Germany. $\mathrm{He}$ had no other girl on his mind as a prospect for matrimiony, but he did not expect to have this one.

Charles and Nicole were nratched to be married because their fathers had quarrelled. François, the petulant younger brother of Henri II, claimed that the Salic law of France, by which a woman could not inherit the throne, applied to Lorraine, then an independent country. By 1618 it was probable that Henri II would not have any boys by his present wife, so that on this theory, François and his heirs stood to inherit the dukedom on his brother's death. Henri II rejected this legal theory and even more vigorously rejected its implications for his family. Nicole, he supposed, would succeed him and be protected in her succession by the strong arm of Louis de Guise.

While the feelings between the brothers were running high, a trusted aide of Louis de Guise was murdered. Henri II beheved that François had helped to arrange the killing. François deduced that he was in jeopardy and in 1618, he departed for Germany and there rendered signal military services to the Catholic League.

The relationship between the two brothers distressed the Emperor and the Pope. Their quarrel jeopardized the security of a sinall but strategic state arrayed on the Catholic side in the Thirty Years' War. The Emperor and the Pope worked to reconcile the brothers. The Pope, Paul IV, sent an emissary to Lorraine with this design. He was Domimic de Calatayud, a charisinatic Discalced Carmelite who had been a hero of the Battle of Prague, carrying the cross before the troops of the Catholic League in their assault. The emissary was well-chosen.

Father Dominic proposed that the brothers be reconciled by their children's marriage. Many noble girls were married at Nicole's age; her youth was no obstacle as she was half a year past the age of consent. Henri II hesitated, but was finally convinced. François considered half a loaf better than none, particularly when half was the way to the whole. Nicole would be controlled by his son, her husband, who would

5. Summarium pro D. Carolo ff.296v-298r.

6. See text accompanying note 83 infra. 
rule the dukedom. He agreed to be reconciled.

Consanguinity in the second degree was an impediment to the union, but it was certain that the Pope would grant the dispensation. While waiting for it to arrive from Roine, Father Dominic lost no time and officiated on May 22, 1621, as Charles and Nicole were wed. The point of this anticipation of the Pope was to seal the agreement of the fathers as firmly as possible. Yet ecclesiastical propriety was also respected. Consummation was postponed till the dispensation arrivedas it did within weeks of its request. On Trimity Sunday, June 6, 1621, the marriage of Charles and Nicole was again celebrated. This time Jean des Porcelets de Maillame, the Bishop of Toul, officiated in the palace chapel of St. George. The families and a huge crowd of notables of the realm attended, the people of the town celebrated, and both Nicole and Cliarles appeared to be elated. ${ }^{7}$

Charles did not find life with his twelve-year old cousin very agreeable. He murmured about the fate of princes forced to marry for reasons of state. ${ }^{8}$ But Nicole fell in love with Clarles.

Three years later, in 1624, Duke Henri II died. The EstatesGeneral of Lorraine, called into session, acknowledged his brother François as successor. After enjoying the title for a week in order to establish that the succession passed through him to his lieir, François resigned. ${ }^{9}$ Thereafter Charles and Nicole reigned as jomt sovereigns.

Their domestic life, meagre as it was, might have gone on mdefinitely if it had not been interrupted by great political events. Charles exercised his martial temper by actions which provoked his neighbor France, then under the government of Cardimal Richelieu. Richelieu saw the advantage of dommating Lorraine, and lie was not sorry to be provoked. In September, 1633, a French army invaded Lorraine and took the capital, Nancy. ${ }^{10}$ Charles fled. Accompanied by some of his troops, lie was permitted to enter the neighboring state to the south, Franche Comté, and he took up residence there in Besançon.

Nicole stayed behind in Nancy. When Charles left in the midst of war she did not expect the separation to be long. She never expected it to last twenty-three years. After the Frencli took Nancy, Nicole's freedom of movement was restricted, although she was not imprisoned. Her sister Claude escaped in disguise; so did her sister-inlaw, Henrietta. ${ }^{11}$ Nicole hesitated, and lost the opportunity for freedom.

7. Summarium pro D. Nicole ff.200r-v.

8. Summarium pro D. Carolo f.295r.

9. 1 F. DES ROBERT, supra note 2 , at v.

10. Id. at vi-vii.

11. 3 A. CALMET, supra note 2, col. 266; Taveneaux, Les Mariages de la Maison de Lorraine-Vaudémont, 32 LE PAYS LORRAINE 136 (1951). 
In May 1634, the French moved her to Paris. As de Brassac, Louis XIII's commander in Lorraine observed, she went at the King's order, against her will. ${ }^{12}$ She had no means to resist. Not permitted to leave the French court, she lived on a small pension from Louis $\mathrm{XIII}^{13}$ and was in the position of a pawn for Richelieu.

Charles seemed to miss Nicole. At least he worried about her and about what use would be made of her by his enemies. He wrote ler while she was still at Nancy, saying, "I die not hearing news of you." He wrote her on April 6, 1634, after her removal to Paris, assuring her that, whatever his fate, "all which will remain to me in this world will be absolutely in your hands." ${ }^{15}$ He wrote her again on June 16,1634 , referring to matters of which, he said, "I desire no person in the world to see or know of except you." 16

These letters might be attributed to a desire to placate Nicole in order to keep her from becoming a tool of Richelieu; or they could be taken at face value as testimonies of affection. They reflected no doubt that Nicole was his wife. Doubts on this score assailed Cliarles only after he became better acquainted with Béatrice de Cusance.

Béatrice was the daughter of the Marquis de Bergues, then dead. She lived im Besançon with her wealthy widowed mother, the Marchionness de Bergues. Béatrice was a great beauty-painted by Van Dyck as one of the great beauties of the European world-and she had great spirit. In 1634 she was twenty. ${ }^{17}$

Charles, a bored and lonely husband of 30 , gallant military hero down on his luck, ex-duke in exile, met Béatrice, a star im any circle and beyond challenge the belle of Besançon. As the acquaintance ripened, reports reached Nicole, who began to worry. Cliarles wrote her upbraiding her for her suspicions. He denounced as traitors those who had made "these wicked reports" to ler. "I will be," he declared, "with passion all yours." 18 Later he wrote, "I pray you always to love me and to believe that my greatest care is to know how you may be happy." 19

These letters-available to posterity through the later exertions of Nicole's lawyers-were not necessarily insincere. Charles liked to please the person he addressed, and he knew what Nicole wanted to hear.

12. Pfister, Les Mémoires du Comte de Brassac, in 48 Societe 387 (1898).

13. 3 A. CALMET, supra note 2, col. 543.

14. Summarium pro D. Nicole $\mathrm{f} .205 \mathrm{r}$.

15. Id. f.206r.

16. Id.

17. 1 F. DES ROBERT, supra note 2 , at 3.

18. Summarium pro D. Nicole f.207r-v.

19. Id. f.207v. 
Yet the letters, too, could have been cries for help, good resolutions, self-addressed exhortations. In any event, they were written as Charles found himself ever more drawn to Béatrice.

Eventually Charles proposed to Beatrice. Her mother objected that he was already married. ${ }^{20}$ Further developments were postponed when Charles went north to be with the imperial troops at Brussels. His sister Henrietta, in a sisterly desire to keep Charles out of trouble, arranged another match for Béatrice. For some years Béatrice had been thought a suitable party for Eugene Leopold d'Oiselit, Prince de Cantecroix, a Besançon resident of some importance. With Henrietta's assistance the match was made. Béatrice became the Princess de Cantecroix in $1635 .{ }^{21}$

This marriage was not the end of the story of Charles and Béatrice, however. The Prince de Cantecroix died on February 6, 1637. Charles, who had offered "3,000 masses" for this result, was on hand to press his suit with the widow. ${ }^{22}$ Charles and Béatrice were betrothed within a week of the funeral, on February 15, 1637.

They moved fast because Béatrice was pregnant, and perhaps by Charles. Under the circumstances Béatrice's mother agreed to the marriage. She signed the marriage contract assuring that the couple would have from her an ample dowry. ${ }^{23}$

Charles' alma mater, the Umiversity of Pont-à-Mousson, now made a distinctive contribution to his plans. In 1621,16 years before, the students of the University had celebrated his wedding with the making of nuptial songs, epithalmions, emblems, riddles, odes in every metre, epigrams, horoscopes, anagrams in Latin and in French, acrostics of all sorts and in all shapes, quintuplets, diagonals, crowns, hearts, allerions of Lorraine and crosses of Lorrame-all on the names of Charles and Nicole. ${ }^{24}$ Now, more than a decade later, the riddle of how Charles could be legally linked to Béatrice was to be answered by an ex-professor of moral theology at the University, Didier Cheminot. In May 1635, Cheminot, a 45-year old Jesuit and a patriotic Lorramer, was expelled by the French from the University. ${ }^{25}$ He gravitated to the Duke in exile, and in 1637, he became the confessor of botli Béatrice and of Charles. ${ }^{26}$ Without Cheminot's help Charles and Béatrice could have had an affair. Without his help they could not have been married.

20. 3 A. CALMET, supra note 2, col. 325; 1 F. DEs RoBert, supra note 2, at 277.

21. P. MAREChal, UNE CAUSE CELEbre AU XVII SIECLE (1919).

22. 2 F. DEs RoBERT, supra note 2, at 376.

23. 1 id. at 531 .

24. 4 Les etablissements des Jesuites en France depuis Quatre siecles col. 135 (P. Delattre ed. 1956).

25. Id. cols. 130-31.

26. 1 F. DES ROBERT, supra note 2, at 378-80. 
Anxious to have these two souls in his charge in the state of grace, anxious to show his skill, sympathy, and inastery of moral theology, anxious to serve his country, Cheminot was a resourceful casuist and an indispensable advisor.

Cheminot advanced four reasons why Charles' marriage to Nicole was null: First, Charles had lacked free consent, having been coerced by his father. Second, the second marriage ceremony in the chapel of St. George had not been before the parish priest or his delegate as required by the Council of Trent. Third, the papal dispensation from the impediment of consanguinity was invalid. Finally, Nicole was not even a Christian, for she had been baptized by a priest later condemned as a notorious sorcerer. Hence, Cheminot concluded, the marriage was null for coercion, lack of form, consanguinity, and disparity of cult. ${ }^{27}$ Le Moleur, Charles' chancellor; Sonnet, a canon of Besançon; Periquet, a priest of Besançon; and Catulle, Vicar-General of Tournai joined in Cheminot's formal conclusions. ${ }^{28}$ Theirs were not big names, but one could say truthfully that five theologians had held the marriage null.

As nullity of his first marriage was clear, Cheminot reasoned, Charles had a duty to marry quickly. It was a duty owed to his country. He inust provide an heir for Lorraine. In time of war delay could not be tolerated. Any day he might be killed by his enemies and the dukedom deprived of his descendants. He must act, and he need not wait for a formal ruling of nullity by a court of the Church. ${ }^{29}$

The last conclusion-the most vital one if Charles and Béatrice were to marry at once-was the most daring. It meant ignoring, at least for the moment, the mighty judicial structure of the Church. Tomás Sánchez, the inost famous Jesuit authority on marriage, could be read to support this conclusion, but only by forcefully resolving ambiguities Sánchez had left unresolved. ${ }^{30}$ To reach Cheminot's desired result took both ingenuity and chutzpah.

27. Id. On the form of ceremony prescribed by the Council of Trent, see note 119 infra and accompanying text.

28. 1 F. DES ROBERT, supra note 2, at 378.

29. Id. at $378-80$.

30. See 1 T. Sanchez, De sancto matrimonil Sacramento (1693). Sánchez taught that a spouse conscious of the invalidity of his marriage could not be compelled by the Church to have intercourse with his spouse, because to do so would be sin. Id. 2.39.8. Unless there were scandal in separation, there was no obligation to live with the spouse in the invalid marriage, even though the invalidity could not be proved. Id. 2.39.11. Sánchez further discussed the position of a man whose wife told him that she had not given true consent to their marriage. He asked what kind of certitude the liusband must have to act on his wife's admission and concluded, "[t]hat certitude is requred-and is sufficient so that he can believe the woman and enter another marriage-which would make a prudent man morally certain of the fictitious consent of the other." Id. 2.45.4. He added that "hence" the man should submit "to the discretion of a judge" the evidence of fictitious consent for the judge to 
Sincere and strong religious sentiment opposed Cheminot's plan for his penitents. Béatrice's young sister, Delia, was the foundress of a convent of Visitation nuns at Gray. She pleaded with her sister and with Cliarles not to take the step. ${ }^{31}$ Pierre Fourier, a canon regular of the Abbey of Pont-à-Mousson, had been consulted in late 1636, when Béatrice's liusband was still alive, by two clerics favorable to Cliarles. Fourier told thein, "His Highness lias a lawful spouse." Later, as Charles proceeded with his purpose of inarriage, Fourier composed a inemorial on the case and sent an emissary to Besançon to dissuade him. The venerable voice of this religious reformer of Lorraine-a spiritual man who was beatified in 1730-was not enough to shake Charles. $^{32}$ The counsels of the devout were heard, but not heeded.

Still the attitude of Charles and Béatrice was not that of persons flouting the Church and defying it to do its worst. When they caine to niarry, they scrupulously observed the form for the ceremony required by the Council of Trent. ${ }^{33}$ While compliance witl this form was necessary to assure that Béatrice became a legal wife and that Charles got good title to the dowry, their motivations cannot be reduced to the purely cynical or mercenary. They had their confessor's opinion that they were not defying the Church, that they were indeed acting virtuously. They made sure that their confessor was approved by high authority ${ }^{34}$

determine its sufficiency.

These passages did not add up to a clear assertion of the right of a person to determine for himself if he were married, but they were ambiguous enough to support such an argument. A person could in some cases defy the authority of the Church court by not having intercourse. In some circuunstances a person could separate from his spouse without the Church's judgment. By law, these matters belonged to ecclesiastical authority. If a private individual had the moral right at times to ignore that authority in regard to them, why could not an individual, at times, decide for himself that his marriage was null? In his statement on the moral certitude sufficient to "believe the woman and enter another marriage" Sánchez did not refer to the judgment of an ecclesiastical court as necessary before acting on one's subjective conviction. He seemed to suppose that once certitude was reached one was free to remarry, just as earlier he had explicitly argued one was free to refuse the debt and free to separate. However he then qualified his opinion by reference to "the discretion of a judge." He could have meant an ecclesiastical judge who has heard the evidence of nullity in a formal trial. In this sense Sánchez was cited by counsel for the Inquisition, Caesare Carena, who held that any man presuming to unarry without a decision of an ecclesiastical court was to be punished by the bishop even if he subsequently proved to the Inquisition itself that the marriage was null. C. CaRENA, De officto SANCTISSIMI INQUISITIONIS, pt. 2, tit. 5, 5.30 (1655). But Sánchez could have meant to refer to the opinion of a prudent man acting as a judge ad hoc. If the second reading were made, Sánchez could be used as authority for the right, in at least some circumstances, to circumvent the ecclesiastical inachinery.

31. 1 F. DES ROBERT, supra note 2, at 377.

32. Id. at 418-19.

33. See text accounpanying note 119 infra.

34. On March 25, 1637, Charles formally appointed Cheminot his "confessor and counsellor in unatters which concern our conscience," and Mutio Vitteleschi, Gen- 
and that other theologians concurred in his counsel..$^{35}$ The Béatrice who at the end of her life asked to be buried in the habit of the Order of Poor Clares, the Béatrice who is painted in this habit, kneeling before The Mother and Child in the Church of Daubs, Saone, was the Béatrice who asked her confessor how to handle Charles. The Charles who much later wrote his daughter, "Ask God that he give you the grace of dying rather than of offending Him," ${ }^{36}$ was the Charles who had masses offered for the death of Béatrice's husband. However conventional Béatrice's pose, however conventional Charles' piety, it was in these conventional religious categories that they spoke and thought. For them justification in terms of the canomical system of marriage was vital. Legalistic but not necessarily cynical, rationalizing but not nakedly hypocritical, Charles and Béatrice and Béatrice's mother were like the characters in the hypothetical cases in the books of moral casuistry then in their heyday, or like a certain kind of modern busmessman who will try any scheme to avoid a tax if he has the advice of counsel. Charles and Béatrice wanted to achieve their will, they wanted to do what the law on its face forbade, but they wanted to do it legally and with a blessing. They had the blessing.

Charles' physician, Foget, approached the pastor of St. Pierre's parish church in Besançon to arrange the wedding. The pastor authorized a priest of the parish, Antoine Guyot, to administer the sacraments in the house of a citizen nained Daniel Beatrix within the parish limits. On the evening of April 2, 1637, Foget summoned Guyot to this house and introduced him to the waiting couple. Guyot, so he swore later, did not know that Charles was already married. ${ }^{37}$ What he thought of the secrecy, the use of an intermediary, or the unusual setting is not recorded.

Shutters were drawn. Foget and Charles' major-domo appeared as witnesses. Guyot was told that he would be the officiating priest required by Trent and was sworn to absolute secrecy. Charles and Béatrice consented to each other as man and wife. They kissed, drank wine from the same cup, and ate bread from the sanne loaf according to the ancient wedding customs of Besançon. ${ }^{38}$

Despite a façade of caution, the marriage was an ill-kept secret. Charles and Béatrice hived in the same house, and their servants ad-

eral of the Jesuits, formally ratified this appointment. $5 \mathrm{H}$. FoUQUERAY, HISTOIRE DE LA COMPAGNE DE JESUS EN FRANCE 22 (1925).

35. See text accompanying note 28 supra.

36. P. MARECHAL, supra note 21 , at 250 .

37. Testimony of Guyot in an inquiry held by the Archbishop of Bensançon in 1639. Bonnard, supra note 2, 71 SocreTE 232-34.

38. Id. 
dressed her as "Your Highness" when strangers were not around. ${ }^{30}$ In August, 1637, in what was meant to be great secrecy, Béatrice went to the château of Scey to await the birth of her child. A son was born in late September, and in November, 1637, Charles recognized the child as his heir. The baby shortly thereafter contracted a fever, was put out with a nurse, and died in the village of Belle-Herbe. ${ }^{40}$

Tragic as the event was, the couple's rehious advisors no doubt could point to the appropriate scriptural parallel: God had taken from David and Bethsheba the son conceived by them in adultery, the son whose disputable parentage would always have haunted the hine of succession; the next child born to that royal couple, then legally married, had been Solomon. ${ }^{41}$

There are three other marriages relevant to the story-two for the light they throw on the attitudes of Charles' father and the reigning Pope, the other because it involved Nicolas-François, who in strategic ways was the most important person in the story of Charles' annulment.

At the same time that Charles took Nicole as wife, in 1621, Louis de Guise married Charles' sister Henrietta. In this way Nicole's old betrothed was disposed of and brought into the family reconciliation. Henrietta-she who later arranged Béatrice's marriage to the Prince of Cantecroix - was then 16 and had other desires. She ran away and

39. Testimony of Jean Dumny, the duke's surgeon, during the same inquiry. Id. at 235.

40. The paternity of the child born to Béatrice in September was the subject of a celebrated legal proceeding, whose length affords a comparison of civil procedures with canomical ones. At stake was a large trust property (technically property in a fideicommissio). This estate went to the Count of St. Amour if the Prince of Cantecroix, Béatrice's late husband, died without issue. The Prince, believing that Béatrice was pregnant by him, left the property to the unborn child, appointing the Prince's mother Caroline as guardiau. In May 1637, the Count of St. Amour obtained a judgmeut from the Parlement of Dôle that the Prince had died without issue. P. MarechaL, supra note 21, at 27. Caroline refused to accept this result and sought the appointment of a guardian for the child then in Béatrice's womb. Id. at 28. The report of the child's death in November appeared suspicious to Caroline, a woman of great determination. She believed that the true heir had been taken off to Flanders in disguise and another baby buried in his place. Id. at 58-61. In 1640, Caroline persuaded Urban VIII to authorize ecclesiastical inquiry into the child's disappearance and had the Dole judgment appealed to the Grand Council of Malines. Id. at 41,65. In 1643, Caroline's efforts were revarded when her lawyer, an ancestor of the author of this account, tracked down a six year old boy in Antwerp, who Caroline immediately claimed as her grandson. Id. at 89. That same year, she instituted a suit to take the boy from the prostitute who purported to be his mother. During the course of the litigation, the child himself came of age and intervened as a party, and the Count of St. Amour died and was replaced by his son. In 1660, the Council of Malines ruled that the infant who died at Belle-Herbe in 1638 was not Béatrice's. But in 1662, Caroline lerself died intestate; her claim was dismissed later that year. Id. at $131-41$.

41. 2 Samuel 12:18-24. 
hid in a convent, so that her marriage to Louis-supposed to coincide with that of Charles and Nicole-was delayed four days. ${ }^{42}$ The circumstances of this marriage underlined the views of Charles' father on the obedience owed to parents in the choice of a spouse.

In January 1632, Gaston, Duke of Orléans and brother of Louis XIII, inarried Marguerite, another younger sister of Charles. The marriage took place in Lorraine without Louis' permission and was one cause of the French wrath directed at Charles. ${ }^{43}$ Three years later, in July 1635, the Bishops of Montpellier, Sees, Chartres, Saint-Malo, and Nimes reported that French custoin required the consent of the King to the marriage of a prince of the blood. Gaston thereupon announced that he would treat his umion with Marguerite as nul1. ${ }^{44}$ Marguerite appealed to Rome. Urban VIII found the marriage to be unaffected by the uncanonical repudiation. ${ }^{45}$ Hence, before Charles' turn came, Urban VIII had occasion to hear the appeal of a Lorraine princess against a spouse repudiating her on the advice of his spiritual counsellors.

The third and most important marriage involved siblings of the principals. ${ }^{46}$ Nicolas-François, five years Charles' junior, had grown up studiously in his brother's shadow. Destined to replace his brother in an ecclesiastical career, he had been given more time for studies at Pont-à-Mousson. At age 14, his panegyric in honor of Saints Ignatius and Francis Xavier was remembered in the University annals. Equally recorded was the defense of his thesis on "Universal Philosophy" at age 17, sustained before a public which included his father and brother. In the saine year he was made Bishop of Toul-that is, though unconsecrated and not in Holy Orders, he was given the juridicial and administrative powers of the bishop. Urban VIII, noting that the House of Lorraine had been "always regarded as the rampart of the Catholic Church," made him a cardinal when he was $18 .{ }^{47}$ Quiet, studious, welleducated, he waited for his hour.

On January 18, 1634, Charles abdicated the dukedom in his favor, thereby hoping to placate Richelieu. But as long as Claude, Nicole's younger sister, remained unmarried, there was the danger that the French might somehow use her as a clainnant to the throne. NicolasFrançois had never taken Holy Orders. The family had already antici-

42. 1 A. CALMET, supra note 2 , col. $182 ; 3$ id. col. 183.

43. See text accompanying note 10 supra.

44. 5 G. Hantaux \& Duke de la Force, Historre du Cardinal de Richelieu 66-69 (1903). $295-96$

46. See 1 A. Calmet, supra note 2, col. 182; 3 id. cols. 257-59.

47. Bonnard, supra note 2, 71 SoçETE 184. 
pated one contingency in which they would have been in the way. ${ }^{48}$ Now in the year of crisis he was free to meet another family need. He consulted the canons regular as to whether he could dispense himself from any ecclesiastical inpediments to marrying. They consulted their copy of Tounás Sánchez and assured him that he could. ${ }^{40}$ Acting as Bishop he then dispensed himself to marry, and with the French army at the gates of his château on February 11, 1634, he resigned the cardinalate and episcopate and inarried Claude. ${ }^{50}$

Immediately thereafter, the French took Nicolas-François prisoner. The "conscience of the King of France" would not permit the newlyweds to remain alone, as only the Pope could validly dispense cousins to marry each other. No doubt the French commander knew that an unconsummated marriage could always be dissolved. ${ }^{\text {st }}$ Virtually by return mail, however, Urban VIII granted the dispensation, which arrived on March 19,1634, and the couple escaped surveillance to marry again the next day. ${ }^{52}$ Papal chagrim at Nicolas-François' casual treatment of the cardinalate had easily yielded to the desire to frustrate a France allied with the Protestants. Nicolas-François still stood high im Roine. He now held a position of a domestic and political character which would make his standing in Rome of the greatest consequence.

In April 1637, Nicolas-François undertook to give his sister-inlaw Nicole some advice. Perhaps the news of Charles' marriage to Béatrice had already reached him in Lorraine, or perhaps he knew only that it was likely. In any event he did not inention Béatrice specifically, but he did speak generally of the difficulties Nicole might face. He advised her to leave Paris and to seek out Charles; only by being with him could Nicole win Charles back. ${ }^{53}$

The advice may have been sound, but the French would not let her leave Paris. At this point Richelieu saw no advantage in her retrieving Charles. Over a year later, when the fact of Charles' hife with

48. The marriage contract of Charles and Nicole provided that if Charles died without issue, Nicolas-François would marry Nicole. See Summarium pro D. Carolo ff. $303 v-305 r$.

49. The classic Christian notion was that a bishop was married to his see. Thus when it was proposed that Saint François de Sales, bishop-m-exile of Geneva, become coadjutor archbishop of Paris, he declared that he "would wish to be made unmarried only to be no longer married," but that he would not take "the wife of another." 19 Oeuvres 152 (1919); see 9 F. Trocher, SaInt Francors de Sales 647 (1940). 258-59.

50. Bonnard, supra note 2, 71 Societe 201-02; 3 A. CALMET, supra note 2, cols.

51. $1 \mathrm{~T}$. SANCHEZ, supra note $30,2.14$.

52. 5 G. HANTAUX \& DURE DE LA FORCE, supra note 44, at 34; Pfister, supra note 12 , at 379 .

53. 1 F. DES RoBerT, supra note 2 , at $385-87$. 
Béatrice was notorious, Nicole appealed to the Pope for help. ${ }^{54}$

\section{II}

\section{MAGNUM IN CHRUSTO}

Urban VIII had both conciliar and papal legislation-his own in fact-to guide him in responding to Nicole's cry. By the provisions of the Council of Trent, a married man living with a concubine was to be adinonished by the bishop three times, then excommunicated; a woman "living publicly" with an adulterer was to be adinonished thrice and then to be punished by the bishop, with the help of the secular arm if necessary. ${ }^{55}$ These provisions presumably came into play if Charles had merely taken Béatrice as his mistress.

More serious yet was Charles' position if le were found to have married Béatrice when he was already husband to another. Bigamists were customarily claimed by the Inquisition. ${ }^{58} \mathrm{~A}$ bigamist, or polygamist as the inquisitors would describe him, was gravely suspect of heresy. ${ }^{57}$ On this subject Urban VIII had himself pronounced as recently as June 20, 1637. Magnum in Christo ran his bull:

Great im Christ and in the Church is the sacrament of matrimony, as a lawful, indissoluble partnership for life between man and woman, in which by reciprocal consent one must give himself to the other. Therefore, by grave and fitting penalties those are to be corrected, who, unmindful of the commandments of the Lord and putting second their own salvation, do not hesitate to violate the holy laws of this sacrament. 58

The Pope went on to say that reports had reached him of "sons of iniquity" who passed to second marriages in the lifetime of their first wives. He had consulted with the cardinals of the Inquisition, and had

54. 2 id. at 112 .

55. Canones super reformatione circa matrimomium, ch. 8 (Nov. 11, 1563), 9 ConcILIUM TridentINUM 970 (Societas Goerresiana ed. 1965).

56. 47 CONGREGATIO CONCIII, LIBER DECRETOROM 416-17 (1697).

57. C. Carena, supra note $30,11.58$. Carena took the position that where nullity of a first marriage was not clear and a spouse remarried, he would have to prove the nullity to the Inquisition. If he failed, he was punished as a polygamist. If he succeeded, he would still be punished for remarrying without a church court's judgment. Id. 5.30 .

A contemporary case from Cremona showed the limits of the Inquisition's mercy: A woman who remarried without adequate proof of her husband's death-he was in fact alive-was sentenced to abjure her heresy de vehementi and to work at the Hospital for Mendicants for six months. Ordinarily, the penalty was much harsher. Id. 4.29.

58. Urban VII, Magnum in Christo (June 20, 1637), in 14 Bullartum DIPLoMMATUM ET PRIVILEGIORUM SANCTORUM RoManoRuM PONTIFICIUM 595 (1868) [hereimafter cited as BuLLARIUM]. 
determined a condign punishment to repress this practice. He decreed that such men were to be "condemned to the galleys in perpetuity."

This constitution was perhaps drafted before the Pope heard of the second marriage of Charles; yet its timing - three months after the event and two months after Nicolas-François could have brought it to the attention of Rome-is coincidental enough to make one suppose that Charles may have been one of those so anonymously classified as sons of perdition. As events developed, however, no such crude and general legislation was to be applied to Charles. The bull stood as testimony to the official Roman view of the man who challenged the doctrine on marriage by taking a second wife. Nicole had set in motion a formidable machine.

To the attention now given his affairs by Rome, Charles had but one answer: The adviser who had told him that he was within the law would be given the opportunity to persuade the central authorities of the soundness of his opinion; Father Cheminot would be sent to Rome. Cheminot carried with him a memorial to the Pope which he had prepared and Charles had signed. In it Charles explained how the marriage with Nicole was null, and how his duty to his country had required him to marry Béatrice. Béatrice, he was made to say, was his "wife of conscience." "5

In a separate memorandum to Cardimal Barberimi, the Pope's nephew and chief aid, ${ }^{60}$ Cheminot set out the techmical way in which the Pope could handle the case and offend no one. The requirements of "the internal forun" and "the external forum" were to be kept distinct. The implied suggestion was that while Charles might not have a provable case in the ecclesiastical courts (the external forum), he could be told that morally, in his conscience (the internal forum), he was justified in his actions. In any event the Pope was requested to cominunicate whatever he wanted to Charles privately before it was published; Cheminot wanted a chance to review the decision. He added, as would any respectful advocate, that Charles was ready to obey whatever the Pope should ask. ${ }^{61}$

Cheminot also took the initiative in getting support from his Jesuit colleagues. He constructed a hypothetical case involving one Titius and one Bertha. They were described as having "contracted marriage through the kind of fear which would affect a steady man."02 The hypothetical gave no himt of the real parties. This textbook example was then circulated in the Jesuits' Roman College, and Cheminot got

59. Bonnard, supra note 2,71 SocieTe 249.

60. See text following note 67 infra.

61. Bonnard, supra note 2, 71 SocIETE 250-51.

62. $5 \mathrm{H}$. FOUQUERAY, supra note 34 , at 28-29. 
thirteen theologians, including the famous Juan de Lugo, to pronounce the liypothetical marriage invalid. He apparently got other theologians, although no Jesuits in Rome, to agree that in the described circumstances the parties did not lave to wait for a decision from a churcl court. ${ }^{63}$ Cleminot had achieved the equivalent of a ruling by the staff of the Federal Trade Commission that an accomplislied merger was legal. But the scrutiny of more powerful agencies and more important persons was still necessary.

Coercion as a ground for annulling an arranged royal marriage was an old ploy. In both the 1498 annulinent proceedings of Louis XII against Jeanne de France and the 1599 annulment proceedings of Henri IV against Marguerite de Vadois, coercion of the bride had been alleged. As precedents in a strict legal sense, neither case was very useful. In both, other grounds-consanguinity and spiritual relationship-were alleged, and the judgments of nullity did not make plain the basis of decision. As precedents in low a marriage miglt quickly be annulled if the Pope was willing to cooperate, however, they were highly instructive. In both the trick had been turned by persuading the Pope (Alexander VI and Clement VIII, respectively) to name judges-delegate who would act in his naine without the case coming to Rome for decision. In both the process had taken less than a year once the Pope had agreed to the procedure. ${ }^{64}$

Through Cleminot, Charles asked that the Bishops of Toul, Metz, and Verdun be appoimted by the Pope to hear his case against the validity of the marriage with Nicole. ${ }^{65}$ The Bishop of Toul was Charles Christian Gourray, who had been Nicolas-François' suffragan simce 1624 and had become Bishop of Toul under him in 1636; Charles gambled on his loyalty. Who the Bishops of Metz and Verdun would have been is not clear, since in the confusion of ecclesiastical affairs in the area there were no bishops recognized by the Pope in these cities. ${ }^{66}$

Nicole, herself well-counselled, responded to the legal petition by recusing all three nommees as prejudiced. She asked Urban VIII to judge in person. She also wrote Charles directly:

You are going to expose us in the theatre of the world . . . to make those who once pitied our condition now laugh at our misfortune ... I have been so long incredulous about my disaster. ... I loved you passionately. . . . You will one day return to yourself,

63. Id.

64. M. Kospise, Divorce et dynastre 121, 184-85 (1910). As Henti IV's chief negotiator in Rome explained in 1599, there was "less rigor" when a marriage was entrusted to papal commissioners. 3 CARDINAL D'OSsaT, LeTtRes no. 189 (1732).

65. 3 A. CALMET, supra note 2, col. 385.

66. See 4 Hibrarchia catHolica 240, 349, 370 (1935). 
and you will regret having so mistreated one who loves you more than life. . . . All your outrages have not uprooted from my heart the affection I have for you. ${ }^{67}$

In Roine the decision of how to handle the case in its preliminary phase rested largely with one inan-Francesco Barberini. Barberini was "the cardinal-nephew," the institutional embodiment of that nepotism which many Popes had thought necessary to einploy in government. He was also, as the inner organization usually called him in memoranda, "the cardinal padrone,"-_the cardinal boss,"-or "the director of affairs." In 1639 he was a veteran of 16 years of high office, having been created a cardinal by Urban VIII at the age of 26 . In those 16 years of service he had reaped a great fortune, and he had been the intelligent instrument of the will of his imperious uncle. Now at 42 , he was in charge. His uncle was far from senile, but he was 71 and accustoined to trusting his nephew. The Secretary of State, nominally the Pope's prime minister, was Cardinal Cava, but Barberini, holding the office of Prefect of the Holy Office of the Inquisition, was in fact above him. In an affair of this kind, involving high political interests and yet presenting questions of special interest to the Inquisition, Barberini might be expected to take personal control. ${ }^{08}$

Quite probably Barberini was advised on the law of the case by Giovanni Giacomo Panziroli, an auditor of the Rota. For further advice, Barberini gave Cheminot's memo to two theologians, Giustiniani and Hilarion. Both reported back that it was very unlikely that Charles' marriage with Nicole was null.00

Upon receiving this preliminary report, Barberini quickly proceeded to isolate Charles from his erring counsellor. Cheminot's standing with the Jesuits was not at its high point. His advice had been sufficiently individualistic to cause brother Jesuits in Besançon to complain to Vitteleschi, the General of the Jesuits, about him. When Chemmot had accompanied Charles to Brussels early in 1639, the Jesuits of Brussels had refused to receive him at their college. Barberini now wrote the General that Cheminot should be rebuked for the partisanship with which he had defended his advice. In the face of this pressure, and with their own men in the field at least divided, the Jesuits at headquarters were not prepared to back up Cheminot, however many theologians subscribed to his hypothetical. Nothing stood in the way of action against him at the direction of the Holy See. By brief of June

67. Bonnard, supra note 2, 71 Societe 239-42.

68. See generally A. KraUs, Das PAPSTLIChte StaAtsskretariat Unter Urban VIII 12-22 (1964); Grisar, Papstuichte Finanzen, Nepotismus und KIRCHENREChte UNTER URBAN VIII, appearing in 7 MiscelLANEA hisToRIAE PONTIFICIAE 244 (1943).

69. See generally A. KRAUS, supra note 68, at 30-31; Bonnard, supra note 2, 71 SOCIETE 252. 
18, 1639, Urban VIII ordered Jacques Boonen, Archbishop of Malines, to conduct an inquiry into Cheminot's conduct. ${ }^{\text {70 }}$ If he was found to have counselled Charles' unarriage to Béatrice, he was to be imprisoned or suspended from the exercise of his priestly functions. ${ }^{71}$

In the same month the first response of the Holy See to the marriage was broadcast to the diplomatic service. Barberini advised the Nuncios (papal ambassadors) to the Einperor, France, Venice, Poland, Savoy, Florence, Naples, Cologne, and the Swiss of Urban VIII's initial impression of the case. The Pope, they were told, had heard that Charles had fallen into the error of "by his own authority repudiating the duchess of Lorrame" and of "temerariously contracting a new marriage with the princess of Cantecroix." 72

To Claude d'Achey, Archbishop of Besançon, went a third directive. The Pope commissioned him to determine if Charles and Béaatrice had in fact gone through a marriage ceremony. ${ }^{73}$ Charles was close to being tried for polygamy.

Secret hearings were conducted early in September 1639 by Archbishop d'Achey. Charles and Béatrice were not heard, but imdisputable evidence of their wedding was furnished by Father Guyot, who had celebrated it. ${ }^{74}$ Barberini now had in hand all he needed to make Charles' life unbearable.

On October 14, 1639, Urban VIII upheld Nicole's complaint against the judges nominated by Charles. He wrote Charles that the matter had been assigned for hearing to Jacques Boonen, the Archbishop of Malines, within whose jurisdiction Charles fell as long as he resided at the iniperial court at Brussels. ${ }^{75}$ At the same time he assured Charles that the case would be heard by a special commission of prelates if "really, truly, and canonically" he would separate from Béatrice. Boonen was simultaneously directed to press for this real separation and to require Béatrice to enter a convent until the case was decided. ${ }^{76}$

Nicole did not remain entirely passive. On January 7,1640 , she pernnitted a public manifesto to appear in her name, addressed to

70. 5 H. FOUQUERAX, supra note 34 , at 26.

71. Id.

72. Bonnard, supra note 2, 71 SocIETE 253.

73. Id. at 232 .

74. Id. at 233-38.

75. Boonen, a graduate of Louvain and a secular lawyer who had become priest at the age of 38 , was no man to trifle with. He had been a bishop for 22 years and had been made Archbishop of Malines in 1621. In 1639 he was 66, was enjoying a reputation as a reformer, and was the willing recipient of directives from Rome. See P. Claessens, Histoire des ARcheveques de Malines 254-60 (1881). 526.

76. Bonnard, supra note 2, 71 Societe 254; 4 A. CALMeT, supra note 2, col. 
Charles. She spoke because "in our name the sacraments are besmeared and especially that sacrament which represents the indissoluble bond of Jesus Christ with his Church."77 The nub of the interest of the case for Catholic Europe lay in that theological symbolism requiring indissolubility.

Charles treated Nicole's memorial as propaganda from Richeheu. In his capacity as a successful general for the Emperor, Charles remained at the imperial court in Brussels, insisting that Béatrice be treated as his wife. Archbishop Boonen was in no position to shake him. This sorry state of affairs, as it seemed to Stravius, the secretary of the nunciature in Brussels, was reported to Rome in March, 1640. Cardinal Barberini replied at once, instructing Stravius to try a "sweeter and suaver" approach; if that did not work, harsher measures would be necessary. ${ }^{78}$

Father Cheminot was still at the root of the problem in the minds of some authorities. Nicolas-François had written the General of the Jesuits on July 2, 1639, warning him about Cheminot. Urban VIII, despite his own suspicions, still referred to him as "our beloved son" in his October 14, 1639, note to Charles. Nicolas-François then caught Cheminot on his way back from Rome and had him detained in Nancy in the fall of 1639. The answer of the Roinan theologians to his hypothetical was found on his person, and Nicolas-François wrote angrily to the General demanding an explanation of this extraordinary opimion of Jesuit theologians. Vitteleschi replied that the theologians had not known that the hypothetical referred to actual persons, nor had they been given any concrete circumstances; they had but answered an abstract inquiry. Cheminot, however, had been allowed to rejoin Charles in Brussels, and Boonen was no inore able to shake him from Charles than to separate Charles from Béatrice. ${ }^{70}$

After Charles' public display of Beatrice in Lorraine, the Pope was heard to describe Cheminot as a "bad man." Thereafter the General of the Jesuits did his best to detach him from Charles. On July 14, 1640, Vitelleschi ordered Cheminot, "by the virtue of holy obedience," not to speak to anyone of Charles' inarriage. A series of letters from Jesuit headquarters pressed hoine the message; the fifth and last warned him that he would be ipso facto excommumicated if he persisted in his disobedience. ${ }^{30}$ Cheminot, however, persisted.

Galileo, famous scientist and one-time friend of Urban VIII, had published his Dialogue on the Great World Systems in February, 1632,

77. 2 F. DES ROBERT, supra note 2 , at 202.

78. Bonnard, supra note 2,71 Societe 256.

79. 5. H. FoUQUERAY, supra note 34 , at 28-31.

80. Id. at 30-36. 
been summoned before the Inquisition in October 1632, been put on trial in April 1633, and been sentenced June 22, 1633. ${ }^{81}$ Monarchs, ex-monarchs, and successful generals, however, were different from scientists. They were also harder to catch. The Pope continued to choose a course milder than that which the full rigor of the polygamy laws permitted.

Sweeter and suaver methods continued to be the order of the day, although the Barberini will to bring Charles to book did not waver. On October 5, 1640, Urban VIII wrote Charles once more urging him to separate from Béatrice. The Pope, as an old friend of his family, still wanted "to act paternally." Béatrice, he added, need not enter a convent. She could go to Lucerne, although she must not see Charles while the nullity of his marriage to Nicole was being tried. ${ }^{82}$ This tone, this concession, the model of reasonable compromise in Roinan eyes, did not strike a response in Charles.

In March 1641, Charles came to Paris to talk to Richelieu. He would not stay with Nicole at the family house in Paris, but it was arranged for him to see her. He made the gallant renark on the beauty of her arms, ${ }^{83}$ but he addressed her as "my cousin." She asked, "Am I no longer your wife?"84

On March 29, Charles signed a humiliating peace treaty with Richeheu in return for which he was given back his dukedom in Lorraine. Brother Nicolas-François, the nominal duke, protested the treaty, but he was in Vienna, and no one was in a position to prevent Charles from resummg his old role. ${ }^{85}$ Charles returned to Lorraine, taking with him Beatrice as his duchess. For Lorrame the return of the old duke was a triumphant occasion. For his alma mater, Pont-àMousson, whose students had been dispersed by war and whose faculty had been so harrassed by the French, the return marked the resurrection of the University. Patriotism as much as theology accounted for the warm reception Charles and Béatrice received froin the largely Jesuit faculty when they visited the University on June 2, $1641 .^{86}$

Having Charles back in Lorrame in a posture that the Holy See regarded as polygamous was especially galling to the Barberini. Respect for a ruler could not outweigh the harm done by such a public display of defiance. Shortly after his return in 1641, Toccius Gerard, a German

81. See G. De Santillana, The Crime of Galileo 187-306 (1955).

82. Bonnard, supra note 2,71 SocIETE 257-58. See also 4 A. CALMET, supra note 2 , col. 526.

83. See text accompanying note 6 supra.

84. 3 A. CALMET, supra note 2, col. 543; 1 H. Fovqueray, supra note 34 , at 33.

85. 4 A. CALMET, supra note 2 , cols. 520-22.

86. Id. col. $526 ; 5 \mathrm{H}$. FOUQUERAY, supra note 34 , at 34 . 
Jesuit, was ordered to travel to Lorraine and personally inform Father Chemmot of his excommunication. The mission was at the risk of the messenger's life, given Charles' and Béatrice's sensitivity to efforts at interfering with their state. But he executed his charge to the letter, although without immediate effect. ${ }^{87}$ On June 1,1641 , another warning letter to Charles from his paternal pastor in Rome arrived. Charles still did not comply. ${ }^{88}$

As a last check on precipitate action by the Holy See, Barberini arranged for a commission of cardinals to give their opinion to the Pope. In all probabihty, Juan de Lugo, Cheminot's chief catch in the signatures on the hypothetical, now the most promiment theologian in the College of Cardinals, joimed in the opinion now given Urban VIII. As in the Galielo affair, the Pope had taken to heart what he regarded as an attempt to acquire an intellectual ascendancy over him. The opinion obtained by Cheminot on his hypothetical had been "fraudulently and treacherously extorted from certain theologians," said the Pope. The theologians, informed of the true facts, revoked their responsum..$^{80}$

After hearing from his cardinals, the Pope took the ultimate step within his power. On February 13, 1642, he signed a bull describing Charles' affair as "a scandal" and "a detestable offense known to all the Christian Commonwealth." Charles and Béatrice were excommunicated and were to be avoided by all Christians. On April 9, 1642, the bull was published with the direction that it be posted in Lorraine and announced in the churches on three successive Sundays. ${ }^{90}$ Thus, in its own sweet time and way, taking about three years from the date on which official urging had begun and five years froin the date of Charles' wedding to Beatrice, the administrative machinery of the Curia had moved decisively to protect the institution of marriage, its own jurisdiction, and the rights of Nicole.

Charles' first response to the bull was defiance. It was, he declared, founded on erroneous facts and, therefore, null. He appealed "from the Pope badly inforined to the Pope better informed." The Attorney-General of Lorraine issued a brochure bitterly attacking the nepotism of the Barberini rule, the espionage of the nuncio, and the tyranical behavior of Archbishop Boonen. ${ }^{01}$

No doubt the case of England's Henry VIII was well in mind when such ducal wrath was shown, and a ruler less devoted by ancestry and conviction to the Catholic Church might have been indeed tempted

87. 5 H. FoUQUERAY, supra note 34 , at 36 .

88. Bonnard, supra note 2, 71 SocIETE 258.

89. 4. A. CALMET, supra note 2, col. 526.

90. Id. cols. 525-28.

91. Bonnard, supra note 2, 71 SocIETE 260-61. 
to suggest that he always had the option of a different ecclesiastical regime. But all of Charles' blustering did not frighten the Barberini nor improve his own position ecclesiastically.

A year and a half after the bull, two years and a half after his own excommunication, Cheminot capitulated and sought pardon. The Jesuits sent him to do penance at Genoa, thus depriving Charles of the counsellor who had always sustained him..$^{22}$

The impasse between Charles and the Pope ended when Urban VIII died on July 29, 1644, and was succeeded by Gianbattista Pamphili, Innocent $X$, an enemy of the Barberini. Innocent $X$ was the rotal auditor par excellence become Pope. Born in $1574 \mathrm{im}$ Rome in the family house on the Piazza Navona, he studied at the Sapienza and took a doctorate in canon and civil law. From early manhood to maturity, for nearly 30 years, he labored in the Rota-first as assistant in the studio of his uncle, Auditor Geronoimo Painphili; then as Consistorial advocate in 1601; then in 1604 succeeding his uncle, who becaine a cardinal, as an auditor himself. He was away from the Rota for years as legate and cardinal and was to hold his highest lawmaking office, Prefect of the Congregation of the Council, from 1639 to 1645. But it was the Rota that had formed him and made him. He said himself, "Our exaltation was owed to God and to the Rota."93 Innocent X could be expected to take a personal imterest in what the Rota did, especially in a big case.

The hostility of the new administration to the Barberini may have helped persuade Charles that the time was ripe to have his case heard in Rome. After "eight whole years without being separated,"94 Charles arranged to live apart from Béatrice long enough to get his excommunication lifted. ${ }^{95}$ In 1646 , Innocent $X$ issued a special papal rescript setting the case for trial in the Sacred Roman Rota..$^{96}$

Proceedings in the Rota then stayed in abeyance while the family of the principals tried to work out a settlement. Gathered in conclave in Paris, the primces and princesses of the House of Lorraine deter-

92. $5 \mathrm{H}$. FOUQUERAY, supra note 34 , at 36 .

93. 2 E. Cerchiari, Sedis auditores causarum sacri palatil apostatici seu SACRA Romana Rota 164-65 (1921).

94. P. MAREChaL, supra note 21 , at 259.

95. 3 A. CALMET, supra note 2, col. 418. Charles' reliance on this shift in papal power may have been misplaced. While it is true that Innocent $X$ represented a major break froin 20 years under the Barberini, in legal inatters there tended to be continuity. Auditor Panziroli, Francesco Barberini's old legal advisor, liad become Secretary of State. Moreover the Pope himself, anxious to preserve the lronor of his old house, would make certain that the handling of Charles' case would be a credit to the institution that had shaped him.

96. Toul, June 26, 1648, 10 Decisionum recentiorum 380 (1716). 
mined that husband and wife should make up their differences. As a result of this resolution, negotiations were opened between the parties with the Nuncio to Paris, Nicolas de Guise, another member of the family, acting as a kind of mediator. On May 26, 1647, in the nuncio's presence, a formal emissary from Charles met a formal emissary from Nicole. Charles' offer was 'to reunite souls and bodies and to supply the consent which may have been lacking on his part in the first marriage." ${ }^{\text {97 }}$ Nicole's response was that she could not accept a clause which would "prejudice her marriage which was valid from the beginning." Negotiations collapsed. Only a judicial decision could determine the status of Charles' marriage to Nicole.

\section{III}

THE LAW CONTROLLING

At this point formal law became crucial to Charles and Nicole. We turn to an examination of what their counsel might have found.

\section{A. Sources of Law}

\section{Canon Law}

If law is conceived of as only that which is written in official lawbooks, then the law was contained in Gratian's Concordance of Discordant Canons, ${ }^{09}$ the Decretals of Pope Gregory IX, ${ }^{100}$ and the canons of the Council of Trent. ${ }^{101}$ Written in 1142, Gratian was a law teacher's collection of conflicting authorities together with his own resolution of the conflicts. First by common acclaim, then by papal action, ${ }^{102}$ this extraordinary teacher's manual became accepted as law itself. Wrenched from use as a teaching instrument, it became a source of familiar texts, decrees, and principles. In 1232, the Decretals were added to Gratian's body of law. This collection, largely made up of papal judgements between 1147 and 1230, was an excellent, concise summary of the case law of the past century. Divided into five major books-Book 4 being devoted to marrage-these case summaries served as a form of legislation, the ratio decidendi of each case being treated as a universal rule, modified as it might be by its companions in

97. 4 A. CALMET, supra note 2, col. 531.

98. Id. col. 532.

99. 1 CORPUS IURIS CANONICI (A. Friedberg ed. 1879) [hereinafter cited as Gratian].

100. 2 CORPUS IURIS CANONICI (A. Friedberg ed. 1881) [hereinafter cited in accordance with canon law custom as $\mathrm{X}]$.

101. 1-13 Concrium Tridentinum (Societas Goerresiana ed. 1963-1967).

102. Gregory XIII, Cum pro munere pastorali (July 1, 1580), in 1 CoRPus rURIS CANONICI LXXIX (A. Friedberg ed. 1879). 
the collection. Innovative papal lawmaking on a large scale ended with this massive effort, but the Decretals were supplemented by a sixth book, the Sext of Boniface VIII, in 1300; by the constitution of Clement V, the Clementines, in 1317; and by the further additions of Extravagants of John XXII in 1330. The decisions made by Pope and Council at Trent from 1548 to 1564 were the last word, largely supplementing but in part overriding earlier provisions by canons in the nature of statutes. Together, these several documents of the past five centuries answered to the description "law" if one sought to know what lawbooks governed Charles' case.

\section{Civil Law}

Written law could also be understood to include the civil law, the law determined by the state. When a canonist in Roine turned to civil law, he turned primarily to the Digest, Code, and Institutes of Justinian. Law in this usage consisted of the responses of Roman jurisconsults and the decrees of Roman emperors as collected, digested, and codified in Byzantium over a millenium ago. Whenever this law did not expressly conflict with canon law, a court of the Church in Rome would regard it as good authority or as apposite precedent; where it did conflict with the canon law, it would often be glossed to harmonize. It was regularly regarded as good current law. Its antiquity, its varied and soinetimes obscure origin, its provenance from Constantinople were ignored.

\section{The Commentators}

Canonical and civil texts did not stand alone. They had been interpreted by glosses, by treatises on specialized subjects, by comprehensive summations, and by colleetions of answers to real or liypothetical cases. Like the responses of the old Roman jurisconsults, these applications of the texts by learned legal writers became difficult to distinguish from the written law itself. No Emperor gave the commentators the ius respondendi. Yet as the right of judges or jurisconsults to declare the law was the power to make law, so the authority attributed by practice to the commentators conferred upon them power to make law, though the fictions employed by courts and lawyers concealed their creative task.

There was no marked difference in the authority accorded an official text and the authority accorded a commentator who had gamed recognition among legal men by the solidity of his work. Only three mimor distinctions were observed: First, the texts were the normal starting poimt for a new decision or a new commentary. A judge or commentator did not so easily jump off from an existing commentary as 
from the official law. Second, flat contradiction of official texts was likely to be unpersuasive; they were better undermined by fictions. In contrast, flat rejection of a commentary was less eccentric. Third, no permanence was guaranteed the commentators-although soine writers, like Hostiensis, had been cited since the thirteenth century-while the official texts were assured of being regarded as relevant by a new generation of lawyers as long as no official action was taken to repeal or amend them.

\section{Case Law}

Of at least equal standing with the commentarics were the decisions of the curial courts. Case law-in particular that decided within the preceding 75 years-formed part of the corpus of written law. Decisions of the Congregation of the Council here held a special place. This committee of cardinals of the Roman Curia was authorized by the Pope to interpret the disciphinary decrees of Trent; its rulings had the force of legislation. Decisions of the Congregation, however, were neither collected nor published, and therefore could only be cited when some commentator imcorporated an account of one of its rulings im his text.

Far more numerous and almost as authoritative were the decisions of the Roman Rota. Two large, albeit unofficial, collections of rotal decisions existed: Diverse Decisions, ${ }^{103}$ collecting a number of cases from 1530 to 1612, and More Recent Decisions, ${ }^{104}$ covering, with greatcr comprehensiveness, the years after 1612 . In addition, many rotal cases could be found in separately published collections of opinions by individual auditors. ${ }^{105}$ These collections were well prepared for practical use. Cases were identified and indexed by city of origin, date of decision, and subject matter. ${ }^{106}$ Each case was preceded by a one sentence summary of its maim holding and by a numbered series of propositions

103. Decisiones diversorum (1636). In rotal citations, the parenthetical year refers to the year of publication of the collection, not the date of decision.

104. 1-19 Decisionum recentiorum (1716).

105. E.g., 1-2 Decisiones coram M. Buratto (1637); 1-3 Decisiones coram J. Emirix (1712).

106. As in modern times, a complex case often called for a number of dccisions on various contested issues. The rotal reporters printed and indexed eacl of these decisions separately by city, date, and subject without regard for the fact that they were all parts of the same litigation. No cominon case name or docket number bound them together. (Of course the city of origin would be the same for all the decisions in a single case, but this city would appear in the names of unrelated cases as well.) To avoid unnecessary confusion to the reader, this Article cites rotal cases by the city of origin, the date of the principal decision, and the page of the particular decision that supports the text. Unless otherwise noted, the dates of subsidiary decisions will not be included in the citation. 
of law extracted from the opinion. The opinion itself was correspondingly numbered. This arrangement was not unlike the syllabus and headnote system of modern American reporters.

The Rota had no strict rule of stare decisis. Individual decisions sometimes conflicted with each other, and the conflicts occasioned criticism. A handbook on the Rota by one of its members found the criticism rash; the conflicts arose, he said, from "the love of truth" and "the necessities of the human condition." ${ }^{107}$ What was important as precedent was not so much the individual decision as the settled line of decisions, the stylus or practice of the Rota. Stylus could take precedence over the Decretals or all the official law denoted by the word ius. The new auditor was advised by another member's handbook that "often more depends on the practice than on the law."108 By two papal constitutions ${ }^{109}$ decisions were to be made "neither against the law [ius] nor against the practice [stylus] and the old decisions of the Rota which have been printed." Doimg "equity" was not an excuse for abandoning precedent. Yet a new path might be taken with "the greatest reason and discussion and by a two-third vote."

\section{B. Charles and Nicole-The Legal Issues}

\section{Canon Law}

\section{a. Coercion}

The main issue in the case, parental coercion, was dealt with by Gratian in terins of the more common case, coercion of the bride. "Can a daughter," he asked hypothetically, "be given to a man against her will?" After a review of authorities-meagre and conflicting in 1142 -he answered with an explicit negative: "By these authorities it is evidently shown that no woman is to be coupled to anyone except by her free will."110

The broad principle enunciated by Gratian was later embodied in several decretals where enforcement of the principle gave it concreteness. In Veniens, ${ }^{111}$ Alexander III disposed of the case of a man compelled to inarry a girl after being found in bed with her by her father. The Pope held that if the fear inflicted on the bridegroom had been one "which could fall upon a steady man," his consent was null. ${ }^{112}$ In

107. J. Emerix, Tractatus SEN Nottita S. Rotae Romae 100 (C. Lefebvre ed. 1961).

108. A. Augustini, Praxis Rotae 18 (C. Lefebvre ed. 1961).

109. Pius IV, In throno iustitiae (Dec. 27, 1561), in 7 BuLlarIUM 155, 156 (1862); Paul V. Universi agri Dominici (Mar. 1, 1612), in 12 Bullarium 58, 68 (1867).

110. Gratian, supra note $99,31.2 .4$ (dictum post).

111. $\mathrm{X}$, supra note $100,4.1 .15$.

112. Id. 
Consultationi tuae, ${ }^{113}$ Honorius III applied tle same standard to women who complained that, compelled by fear, they had publicly consented to marriage while dissenting in their minds. As a consequence of these decretals, a "steady man" was a fictional man of average fortitude who served in fear cases much as a "prudent man" is used to measure negligence in modern tort law.

Betrothals-always easier to dissolve because unconsummatedprovided occasion for expansion of the rules on coerced consent. In De illis qui, ${ }^{114}$ Alexander III taught that the consent of children to a betrothal was invalid if due to "violence." Further, Urban III held that a betrothal was unenforceable where a girl had been "impelled by threats of her parents."115 In the analogous case of religious profession, a vow at "the command of parents" was said to be not bimding. ${ }^{116}$ In Gemma, ${ }^{117}$ the concept of coercion was extended to include the threat of a penalty: A betrothal by the parents of children under seven had provided that a sum was to be paid by wlioever broke the agreement; Gregory IX, observing that marriages "ought to be free," held that collection of the penalty could be enjomed by ecclesiastical censure. Gemma provided a basis for arguing that coercion could be shown in many ways other than actual or threatened violence.

\section{b. Subsequent Consent}

If these canons tended to support the case of one claiming parental coercion, $A d$ id, ${ }^{118}$ a decretal of Clement III, posed a bar. $A d$ id tauglit that after a girl had hived with a man for a year and a half, she could not be lieard to say that slie had married without consent. So long a period of cohabitation tended to show that the complaming spouse, if indeed coerced into the marriage in the first place, had voluntarily consented to the marriage sometime thereafter. Such consent would ratify a marriage otherwise invalid because coerced. Therefore, "delay of such a great time excludes proof" that the marriage was obtained through coercion. If applicable, $A d$ id barred Charles' coercion claim without inquiry.

\section{c. Form of the Ceremony}

All of these canons were cast in a new light by the comparatively recent legislation of the Council of Trent in 1563 prescribing the form

113. $\times$ 4.1.28.

114. $X$ 4.2.9.

115. Ex literis, $\mathrm{X}$ 4.2.11.

116. Quum virum, X 3.31.12.

117. $X$ 4.1.29.

118. $X$ 4.1.21. 
of celebration of a valid Catholic marriage. Asserting the accepted power of the Church to determine competence to marry, the Council legislated the form in terms of capacity: One was incapable of contracting marriage except before one's parish priest, or his licensed delegate, and at least two witnesses. Banns read in churcli three times on feast days were to precede the marriage, and the priest was to record the marriage in an official book. The purpose of this legislation, according to the Council, was to remedy the evils of clandestine marriages, especially those where a secret first wife was abandoned for a second wife publicly taken. ${ }^{119}$ The effect of the legislation on marriages invalid in their inception, but ratified in time, was not spelled out.

A series of decisions of the Congregation of the Council determined that the banns were not necessary for validity, but that the most strict compliance was necessary as to the presence of the parish priest. Far from applying the law only where necessary to carry out its proclaimed purpose, the Rota, too, tended to treat any technical breach of this rule as fatal to validity. It proclaimed as a principle, "The more a matter is one of will [that is, the nnore a matter is one of positive legislation rather than natural reason] the nore it is to be fulfilled in specific terms."120

\section{d. Conclusion}

Taking the canons on their face, Charles could win if he could show coercion. He would be blocked, however, by $A d i d,{ }^{121}$ unless this barrier was interpreted to rest on a rebuttable presumption of ratification or unless the requirement of form set down by Trent applied to subsequent consent to a coerced marriage. If the latter, then regardless of the lengtl of cohabitation there would be no ratification until the ceremony was repeated.

\section{Civil Law}

The most apposite Roman test came from the Digest, Si patre cogente: "If at the compulsion of one's father, one takes a wife one would not take of one's own will, one has still contracted marriage; for marriage is not contracted between the unwilling, and so one seems to

119. Canones super reformatione circa matrimomium, ch. 1 (Nov. 11, 1563), 9 Concrium TrIDENTINUM 968 (Societas Goerresiana 1965). The casting of the rule ou form in terms of capacity to marry reflected a division of opinion as to whether the Church could either change the form of the sacrament of marriage, that is, the exchange of consent, or invalidate the marriage of two persons capable of giving valid consent. See id. at 643-45. But since the Church had already ruled that some persons were incapable of lawful marriage, no one felt able to challenge a new rule of capacity.

120. Florence, June 16, 1579, Decisiones novissorum (1590).

121. X 4.1.21. 
prefer the marriage."122 The reasoning was somewhat paradoxical. It implied that the son preferred marriage to disobeying his father and thus, in obeying, inust be taken to have consented.

Other texts, good by analogy, were to be found in the Code dealing with property. The general rule was that "transactions undertaken because of fear are not to be treated as ratified."123 But the standard set for fear restricted the breadth of this rule. In a title headed "Of those matters done because of force and fear," it was specified that invalidating fear had to be fear of death or bodily harm. ${ }^{124}$ Mere threats or arguments did not suffice; "cruelty of act" had to be proved.125 Fear caused by someone holding at least intermediate jurisdictional authority to $\mathrm{m}$ flict punishment would suffice to invalidate, ${ }^{126}$ but not merely the fear caused by one's adversary being a senator. ${ }^{127}$ Payment without protest inade it improbable that fear was operative, ${ }^{128}$ as did the presence of friends at the transaction. ${ }^{120}$

Taken together, these laws did not recognize fear of one in authority as grounds for invalidating consent unless the person feared was one whose authority permitted him to inflict bodily harm. A father was such a person, but read together with Si patre cogente these provisions probably did not invalidate the consent of a boy getting married under merely moral pressure from his father. Their thrust was in conflict with canons like Gemma, ${ }^{130}$ which treated the fear of losing property as invalidating, and canons like $Q u u m$ virum, ${ }^{131}$ whicle treated a parent's command as preventing free consent.

Measured by the civil law alone, then, Charles did not have a case. In theory, this conclusion did not reduce his rights in canon law. In practice, the harmonization of canon law with civil law could affect the meaning of his rights when his judges considered the canons on coercion.

\section{The Commentators}

The commentators presented a view of the law more favorable to Clarles than either the official canon or civil law texts in two principal respects: First, in the degree of fear necessary to invalidate consent; and second in the standard for ratification of an invalid inarriage. Both

122. Digest 23.2.22.

123. Interpositas, CODE 2.4.13.

124. Si donationis, CoDE 2.20.7.

125. Metum, CoDe 2.20.9.

126. Si per impressionem, CoDE 2.20.11.

127. Ad invidiam, CODE 2.20.6.

128. Quum te non solum, CODE 2.20.2.

129. Transactionem, CODE 2.4.35.

130. $X$ 4.1.29.

131. X 3.31.12. 
of these differences were strikingly illustrated in the work of Tomás Sánchez, a Spanish Jesuit who taught and wrote at Córdoba at the end of the sixteenth century. His great book, The Holy Sacrament of Marriage, ${ }^{132}$ was one of the first investigations of the conditions of Christian marriage by a specialist. Not merely a pioneering effort, his book was to stand for all time as the fullest, most learned, and most astute scholastic treatise on the subject.

\section{a. Coercion}

Sánchez accepted the settled doctrine that a valid marriage required the consent of both of the spouses. If the consent of either had been coerced, the marriage was null. But not every fear amounted to an invalidating coercion. For example, Sánchez set down as a general norm that "reverential fear," such as a subject's fear of his lord or a son's fear of his father, did not invalidate a marriage. As a matter of reason, Sánchez thought, reverential fear "does not seem to have such strength to compel the will that a steady man should be terrified of it."133 The Roman law plainly reflected this approach. ${ }^{134}$ The classical canonists, Innocent IV and Hostiensis, as well as many modern theologians, including Sylvester and Soto, concurred. Sánchez explamed away the canons that appeared to be contrary. Thus, if Charles intended to argue that he was coerced merely because he responded to his father's command, he could find no support in Sánchez.

On the other hand, Sánchez recognized that where reverential fear was coinbined with additional fears or threats, the combination might be sufficiently coercive to invalidate a marriage. The judge must therefore weigh all the facts and circumstances to determine whether consent was freely given. The father's character and his relationship with his children was to be taken into account. ${ }^{135}$ The threats of a father who generally did not threaten idly should be considered more coercive than those of a more even-tempered parent. ${ }^{136}$ Threats could be found in what purported to be mere requests when they were "most pressing, often repeated, and uncivilized."137 By themselves such importunities did not coerce, but, according to the more probable opmion, when they were joined to the reverential fear felt for a parent, they were coercive and invalidated the consent yielded to them. ${ }^{138}$

132. 1-3 T. SANCheZ, De sancto Matrimoni SACRAMENTo (1693).

133. 1 id. 4.6.7.

134. See text accompanying notes 122-29 supra.

135. $1 \mathrm{~T}$. SANCHEZ, supra note $132,4.6 .11$.

136. Id. 4.6.16.

137. Id. 4.7.8.

138. Id. 4.7.7. 
All of this analysis, in its ultimate conclusions so favorable to Charles' case, was counterbalanced by another legal concept-just fear. Just or justified fear was fear felt where the person's own actions warranted the punishment he apprehended. It arose "from the law and the nature of the crime, and hence it comes from withm rather than from without in the sense that the just cause of the fear, its start and root, is within the man."139 For Sánchez the imternal origin of the fear created a vital distinction, or at least he used the distinction to rationahize current social and ecclesiastical practice. An example was a seducer's fear of imprisonment if he did not marry the girl seduced. His just fear did not invalidate consent to marry which he gave in order to avoid jail. Similarly, a man might be lawfully forced under pain of excommunication to carry out his betrothal promise to enter a valid unarriage, for one "is not said to be unwilling when compelled to stand by one's promises." 140

With this large class of coercion treated as innocuous, Sánchez turned to a question critical in the case of Charles and Nicole: Do sons commit a fault in not obeying parents who command them to enter some marriage? If they were guilty of a fault im refusing the command, then coercion to compel compliance might be analyzed as the infliction of just fear. Sánchez declared that ordinarily a son had no duty to obey a father's command of this kind. The great majority of canonists, led by Hostiensis, and the great majority of theologians, led by Scotus, concurred. "As to contracting marriage," Sánchez concluded, "a son is free and sui iuris."141 Yet there was the inevitable exception. "If it is of mucl importance to the parents that the son enter such a marriage, the son is bound under mortal fault to obey his parent commanding it," because "by the virtue of piety, sons are bound to help their parents in need." 142 The exception came close to swallowing the rule. As long as the standard of parental need was not spelled out, the interested parties could argue whether or not a son was bound to obey, leaving the judge to inake, case by case, an intuitive estimation of need and importance. If the analysis of just fear were combined with the theory of filial duty, coercion of a son to enter a marriage "of such importance" to his father would not invalidate the forced marriage. A son who was recalcitrant would be in mortal sin. The cause of his fear would be within. The fear he experienced would be just. Sánchez did not combine these principles into a single statement. If they were combined, and the importance of the marriage to Cliarles' father proved, Charles was out of court.

139. Id. 4.13.3.

140. Id. 4.13.6. But see text accompauying notes 143 \& 144, 199 infra.

141. 1 T. SANCHEZ, supra note 132, 4.23.3.

142. Id. 4.23.4. 
To have a right to coerce, however, was not to have a right to use all coercion possible. Sánchez' own analysis of just fear had shown that the coercion must be appropriate to the situation. His idea was similar to the common law right to defend one's property using no more than reasonable force. Fathers of seduced daughters could coerce the seducers, but not threaten them with death. ${ }^{143}$ The punishment threatened must be proportionate to the interest preserved. Even the ecclesiastical judge acting for the Church in forcing a man to carry out his betrothal pledge did not have unlimited power to achieve this end. A degree of freedom must be left.to the delinquent fiancé, so that in the end his consent to marriage would at least to some extent be an act of will. The judge could compel "moderately, but not conclusively."144 When it came to fathers coercing their sons to obey their commands to marry, what threat exceeded the just ineasure was left to the judgment of the wise.

Concrete contingent facts to be weighed in every case-this was what emerged as decisive in Sánchez' extended analysis. Formulas such as "reverential fear" or "just fear" could have dispensed the judge from thinking and evaluating. In Sánchez' view, however, they became directions to the judge to weigh certain factors with special care; the formulas were not to be automatically invoked. Sánchez left open for decision in each case whether reverential fear had been combined with such circumstances of the parent-child relation that freedom had been denied; and if it had been demied, whether the interest of the parent had been such that piety required the son's sacrifice; and if piety had called for his obedience, whether the parents' measures had still been disproportionate to the parental stake in the issue. One can say that such conclusions decided nothing or that they were sheer common sense. But they decided much in providing guidelines while still insisting that the guidelines not rehieve the judge of the duty of evaluation. They were common sense vindicated by reflection. The average abstraction of the Decretals, "the steady man," melted away and was replaced by a particular person acting in a situation where the intensity and proportionateness of the pressures applied to him were to be individually gauged.

\section{b. Subsequent Consent}

With regard to what looked like Charles' most serious hurdle, the effect of his having lived with Nicole for over twelve years, Sánchez set out the following guidelines: Marriage was constituted only by consent.

143. Id. 4.13.1. See text accompanying note 199 infra.

144. $1 \mathrm{~T}$. SANCHEZ, supra note 132, 4.13.6. 
In the case of coercion a marriage could be made by the subsequent free consent of the one coerced. There was no requirement of simultaneity of consent, so that $A$ could consent at the original ceremony and his coerced spouse $B$ could consent sometime later after all coercion had ceased. ${ }^{145}$ Good subsequent consent was evidenced by coitus, ${ }^{140}$ by continued living together when there was opportunity to leave, ${ }^{147}$ or simply by accepting marriage presents or by calling one another "husband" and "wife."148

These guidelines, if applied to Charles' situation, seemed to preclude his case utterly. Sáncliez, however, did not stop here. First of all, he dispensed with $A d i d,{ }^{149}$ the canon which stood most squarely in Charles' path. $A d$ id would not permit attack upon a marriage after one year and a half of cohabitation. But the great thirteenth century canonists of the Curia, Innocent IV and Hostiensis, had interpreted Ad id's reference to a specific time as "narration of a contingent fact" in the case the decretal decided. Hence, this decretal set no general statute of limitations after whose expiry no action could be brought. Cohabitation was merely evidence of consent, and the length of cohabitation which conclusively betokened consent was left to "the judgnent of a prudent man."150 A prudent man could find consent shown in a month's cohabitation, but he might also find it absent in a decade of life together. Once a statement of a hard and fast line, $A d$ id became a direction to the judge to use his discretion in evaluating the significance of cohabitation.

$A d$ id's once strict time limit having been put aside by interpretation, Sánchez then complicated the requirements for effective subsequent consent. First, he laid down the requirement that the person consenting know that his nuarriage was invalid. If the consent was given under the erroneous impression that the marriage was already valid, it was not true consent. ${ }^{151}$ If one did not know his marriage was invalid, one could at noost "intend to ratify the first marriage," when what was required was intent to enter marriage afresl1. ${ }^{152}$

Sánchez argued further that both spouses might, in certain cases, have to know of the marriage's invalidity to make later consent good. If one spouse had freely consented in the original ceremony while the

145. Id. 4.18.2.

146. Id. 4.18.1.

147. Id. 4.18.3.

148. Id. 4.18.11.

149. $X$ 4.1.21. See text accompanying note 118 supra.

150. 1 T. SANCHEZ, supra note $132,4.18 .6$.

151. Id. 2.34.3, 4.18.5. This is in accord with the general scholastic principle that nothing is willed unless first known.

152. Id. 2.36.3. 
other had been coerced, a marriage could be made if the coerced person alone knowingly consented only if he did so without great delay. Analogy was made to other contracts: power to accept lapsed after a reasonable period of time. A prudent man must judge in the circumstances how long the uncoerced consent of the first spouse lasted-"several months" was a suggested period. ${ }^{153}$ If the free consent of the uncoerced spouse had lapsed, there came into play the same reasoning that required knowledge of invalidity on the part of the previously coerced spouse now giving free consent for the first time. Both spouses' consent had to be knowing.

Mlogically, some fifteenth and sixteenth century writers held that knowledge of invalidity was unnecessary for effective subsequent consent. They argued that a mere "error of law" did not prevent consent to a contract, and to mistakenly believe one was already married was an error of law. ${ }^{154}$ Moreover, the classic canon law did not admit mistake of fact as a general ground for invalidating consent to marriage. One could think one's spouse was rich, beautiful, and virtuous; she could turn out to be a poor, ugly whore and the marriage would still be good. Mistakes as to wealth, looks, or chastity were mistakes as to "quality" and were not permitted to affect consent to marriage..$^{155}$

To meet this reasoning, Sánchez turned to two exceptions Gratian had recognized to the general rule that mistake did not invalidate consent to marriage-mistakes "of person" and "of condition."156 If a man narried $A$ thinking she was $B$, he failed to consent to her person; if a free man married a slave girl in ignorance or her servile condition, his consent was likewise not binding. Similarly, if a man was ignorant of the fact that the woman with whom he was hiving was not his wife, he was in error as to her person and her condition; if he renewed his consent to their marriage in this ignorance, he intended "to consent to his own, when in fact she is not his own." imeffective.

Artificial as Gratian's distinctions were in logic, they were grounded in social realities and had survived in the canon law. Sánchez pressed them and firmly imsisted that if the original marriage was null and

153. Id. 2.32.7, 2.32.12.

154. Latter day courts have confronted a similar problem. Cf., e.g., Williams v. North Carolina, 325 U.S. 226 (1945) (mistaken beief in the validity of a prior divorce no defense to prosecution for bigamy); State v. De Meo, 20 N.J. 1, 118 A.2d 1 (1955) (same); State v. Shufelt, 107 Vt. 358, 179 A. 3 (1945) (same as to adultery); State v. Grengs, 253 Wis. 248, 33 N.W.2d 248 (1948) (same). Contra, e.g., Alexander v. United States, 136 F.2d 783 (D.C. Cir. 1943) (bigamy); People v. Vogel, 46 Cal. 2d 798, 299 P.2d 850 (1956) (same).

155. Gratian, supra note $99,29.1$.

156. Id.

157. 1 T. SANCHEZ, supra note $132,2.36 .3$. 
consent had lapsed, both parties had to give knowing consent afresh for there to be a marriage.

Applying this line of reasoning to his own case, Charles could argue, perhaps plausibly, that he had not realized until 1637 that his original consent was invalid under the law of the Decretals. With even greater plausibility he might argue that since Nicole had never known of the invalidity of his consent, she could never have given the fresh consent necessary to make a marriage even if it were admitted arguendo that Charles, free of coercion, had knowingly consented to take her as his wife solnetime after the ceremony. By what Sánchez characterized as the "much more probable" opinion, there had been no subsequent consent capable of constituting the marriage.

Having established the need for informed consent, Sánchez then set out a second prerequisite for effective subsequent consent. After an invalid marriage had begun, acts evidencing later consent must be done with marital affection. Coitus after a ceremony of marriage was not evidence of consent unless marital affection was present. ${ }^{168}$ The reception of marriage gifts was not evidence of consent unless they were received with marital affection. ${ }^{159}$ Calling one another "husband" and "wife" did not show consent unless the spouses did so with marital affection. ${ }^{160}$ If these deeds were relied upon to prove delayed consent, not only must the deeds themselves be proven, but this special extra factor, marital affection, must be established.

What did Sánchez mean by marital affection? ${ }^{101}$ The expression came from Roinan law. In its initial Roman usage affection (affectio) indicated intent, and "marital affection" overlapped with "consent to marriage."162 The term indicated that a mental element of a particular kind was required to marry-an intent to take the other as a spouse. Marital affection was not "affection for a concubime," but "affection for a wife."163 With this state of mind a master could make his alumnahis freed slave girl-his wife. ${ }^{164}$ Living with a concubine, a man might have children by her and, "affection coming," be so bound to her that the union was recognized as inarriage and the children as legitimate. ${ }^{105}$

In the developed Roman legislation of Justinian, affectio was used

158. Id. 4.18.1.

159. Id. 4.18.11.

160. Id.

161. See Noonan, Marital Affection in the Canonists, in 12 Studis GrutiAN 479

(J. Forchielli \& A. Stickler eds. 1967).

162. Compare DIGEST 24.1.32.13(9) ("Marital affection, not coitus, makes a marriage."), with id. 35.1 .15 ("Consent, not coitus, makes a marriage.")

163. Id. 24.1.3.1(11).

164. Id. 5.4 .26 .

165. Id. 5.27.11. 
in contexts suggesting not only intent but an emotional attitude of inclination and benevolence towards the object of the affection. One could care for a destitute ininor "with paternal affection,"166 treat a fellow soldier "with fraternal affection," "the affection of a grandinother." 168 This ernotional coloring of the term was present in the Code passages on marriage. The inaster married the alumna not only with the intent but with the emotions appropriate toward a wife. The man living with a concubine not only treated her with a new intent but a different emotion. Marital affection in Justinian designated not only a legal will to marry but the feelings which fittingly accompany an intent to treat the other as spouse.

Against the background of the Roman usage, canonical employinent of the phrase occurred. In its primary usage in Gratian, as in Roman law, marital affection served to distinguish lawful inarriage from inerely living together. Two persons could validly marry each other without priest or blessing when, "contemning all those solemnities they couple thernselves to one another as spouses with affection alone."169 A man and a woman are indissolubly united once "they have adhered to each other with conjugal affection."170 Gratian did not define the content of the terms any inore than the Roman law had done; but for him marital affection was a state of mind not necessarily involving procreative intent, ${ }^{171}$ and in the exemplary marriage of Mary and Joseph it was characterized by undivided fidelity to the other. ${ }^{172}$

Alexander III enlarged the range of the phrase's meaning in setting out a formula for use when the Church reunited estranged spouses: The Church's representative was to compel the delinquent husband "to return to his wife and to treat her with narital affection"; ${ }^{173}$ the delinquent wife was to be ordered "to serve the said husband with conjugal affection."174 In this usage nuarital affection was not meant to characterize a kind of consent. It was made the measure for postnuptial behavior.

Marital affection in this extended meaning was more than the characteristic of a single act. It was a continuing and dynamic attitude. As Alexander III directed one husband, he was "to put aside objection and to receive the said Marietta and to strive to love her as his wife and

166. CODE 1.31.1.1.

167. Id. 12.36.4.1.

168. Id. 8.47.10.1b.

169. Gratian 17.28 q.1 (dictum post).

170. Id. 16.32 q.5 (dictum post).

171. Id. 5.32 q.2 (dictum post).

172. Id. 29.27 q.4 (dictum post).

173. Ex parte, X 4.1.9; Proposuit nobis, X 4.9.2.

174. Illud quoque, $\mathrm{X}$ 2.23.11. 
to treat her with marital affection."175 Spouses, Alexander III also taught, were to be exhorted to follow their mates who had been striken by leprosy and "to minister to them with conjugal affection." "170 Intercourse with a leper, dealt with elsewhere, ${ }^{177}$ was not at issue here. What the Pope was recommending was a ministerial solicitude for one's sick spouse appropriate to his status as spouse.

Thus marital affection was defined by the civil law and by the canon law not by an express definition, but by example. In the attitude to a slave girl that made her a wife, in the attitude to a concubine that transformed the relation to one of undivided love, in the attitude of Joseph to Mary, in the attitude of a spouse serving a leprous mate, there was marital affection. Although colored by emotion, it was not lust, infatuation, desire for intercourse, or momentary dehight. It was a will to regard the other in a special way in that special status called "husband" or "wife." If love is understood as more than sentiment, it was love of the other as spouse.

The classic texts of Rome, developed by the canons and the actual experience of marriage, had given marital affection this extended meaning. When Sánchez taught that marital affection was necessary to turn acts between a man and a woman into evidence of consent to marry, he called upon this developed concept. Only acts performed with a loving attitude toward the other as spouse were evidence of consent. No mere evidentiary requirement was set out im this demand. Valid consent to marriage was consent characterized by marital affection, and absence of marital affection robbed cohabitation or coitus of any significance for the making of a marriage. The substantive notion of marriage itself required this result.

If marital affection was so crucial in the civil and canonical analysis of consent, it may seem that this conclusion was obvious enough: Whenever consent was at issue, marital affection must be proved. What was dangerous, even revolutionary in Sánchez, was that he was the first to insist on this point, and he did so only in the limited context of acts establishing delayed consent. Classical canonical practice, despite its use of marital affection as a concept, did not attempt to ascertain the existence of marital affection in the ordinary consent to marry. It could be said that when one agreed to take the other as a spouse, marital affection was presumed from the language used. But the concept referred to a state of mind and heart, not language. If marital affection

175. Veniens, $\mathrm{X}$ 4.1.13. The phrases "to love her as a wife" and "to treat her with marital affection" were coordinate. Bernardo of Pavia, the compiler of the Decretals, considered the two phrases equivalent and eliminated the first one as duplicitus.

176. Perveniens, $\mathrm{X}$ 4.8.1.

177. $\mathrm{X}$ 4.8.2. 
was essential to consent, why could not the presumption of its presence be challenged, its absence shown? If Sánchez was right in requiring that marital affection be proved to characterize the acts constituting later consent, rigorous logic led to the same requirement being imposed wherever the validity of consent was questioned.

To use marital affection as a criterion for measuring the validity of any consent to marriage was to look to internal states of mind, to explore the kind of love required towards a spouse, to challenge, perhaps, the existing social order's whole system of arranged inarriages. The canonists never entirely identified the canon law with the existing social order, but they were inevitably influenced by its practices. Sánchez, the boldest and brightest of them, did no more than open up the possibility for a wider use of marital affection in measuring the validity of consent. Marital affection remained a concept with an ancient lineage, a range of meaning, and a potentiahty for unsettling development. In it Charles' lawyers had a concept which could be the heart of their case, especially if they applied it to the area of initial consent-an area where Sánchez had not pushed his logic.

\section{c. Form}

Having complicated the substantive requirements for giving subsequent consent to a coerced marriage. Sánchez then proceeded to open the door even wider for the petitioner seeking annulment of his marriage. Sánchez taught that subsequent consent, to be valid, unust comply with the Tridentine form. ${ }^{178}$ In theory, this conclusion followed almost necessarily fron the notion that parties subsequently consenting to an invalid marriage were contracting anew, rather than merely ratifying a voidable marriage. ${ }^{179}$ In practice, it meant that few marriages indeed would ever be proven by subsequent consent since it was highly unlikely that parties subsequently consenting would bother to repeat the elaborate ritual required by the Council of Trent. By this test, if Charles could prove that his marriage was coerced, he was home free.

Sánchez, however, qualified the simple rule. If an impediment to valid consent had been a hidden impediment, he taught, later consent need not be given in the Tridentine form. His reasons were twofold: First, the rationale of Trent, the prevention of clandestine unarriages, did not extend to marriages already in appearance contracted in the face of the Church. Secondly, any other rule would lead to much scandal - a number of apparently valid marriages would not be validated by later consent because of the absence of any later ceremony accompany-

178. See 1 T. SANChez, supra note 132, 2.37. See note 119 supra and accompanying text.

179. See text accompanying note 152 supra. 
ing the consent. ${ }^{180}$ Posttridentine commentators, the Congregation of the Council, and the Sacred Penitentiary under Pius V were cited for this proposition. But if the impediment had been public, then later consent had to be given in the Tridentine form.

Everything in this analysis depended on the definition of a "public impediment." Here too, Sánchez gave a definition weighted in favor of a petitioner for annulment: A public impediment was any impediinent that could be proved by two witnesses other than the spouses themselves. ${ }^{181}$ Sánchez thought that lack of internal consent due to fear was not such an impediment on the grounds that it would not be so provable, and that fear not perceived by the priest or formal witnesses to the original ceremony was, by definition, hidden. ${ }^{182}$ But there was no logical necessity that the formal witnesses to the ceremony also witness the alleged coercion. If coercion could in fact be proven by two independent witnesses, then by Sánchez' own reasoning subsequent consent would have to be accoinpanied by a new ceremony that complied with the prescriptions of the Council of Trent. ${ }^{183}$ Under this theory, if Charles could prove coercion by two witnesses, lie sinnultaneously established the right to prove that he lad not consented later in the public form required by Trent.

\section{d. Conclusion}

Under Sanchez' view of the law, if Charles could establish that lie had been coerced into marriage, he could overcome the hurdle of $A d$ $i d^{184}$ by showing lack of knowledge of the marriage's invalidity on the part of either spouse, lack of marital affection either at the time of the wedding ceremony or accompanying the acts said to constitute subsequent consent, or lack of an official cereinony accoinpanying the subsequent consent.

The flexibility that the law took in Sánchez' hands could have been revolutionary if the law were adninistered by judges inclined to challenge the existing social order. Judges are not apt to be unconventional, however, and in the expectable situations, Sánchez' views left roonı only for a wise discretion, hedged by a rule. The flexibility he gave could not bear fruit if the judge were simple or corrupt. But for the wise judge, Sánchez' balancing of values opened the way for informed caseby-case decisions. The decisive weight Sánchez attached to the facts of each case invited the litigant with good facts to try his case.

180. 1 T. SANCHEZ, supra note $132,2.37 .3$.

181. Id. 2.37.11.

182. Id. 4.18.12.

183. In this analysis, the decretal $A d i d, \mathrm{X} 4.1 .21$, was completely overriden by the legislation of the Council of Trent.

184. $\mathrm{X}$ 4.1.21. 


\section{Case Law}

Four leading early-seventeenth century cases dealt with issues raised in Charles' litigation. In Seville, June 18, 1607,185 decided by Alessandro Ludovisi (later Pope Gregory XV), Antonia Marchioness de Alcalá was married to Don Filippo de Aragon y Guzman. She claimed to have been coerced into marriage by her father. Ludovisi set out the following as evidence of coercion: She wanted to marry another, which tended to show that her marriage to Don Filippo was against her declared will. She had wept, protested, and pleaded that she not be forced to marry Don Filippo. Her father threatened to disinherit her if she refused to obey. After the marriage she was "deformed" by sadness. Ludovisi also noted that her father was severe, bitter, and "very terrible" when crossed, although the parties' witnesses were in direct conflict on this point. Ludovisi found these facts sufficient to invalidate the marriage on the ground of coercion. ${ }^{186}$ Following Sánchez' analysis, Ludovisi held that while reverential fear of a father was not itself coercive, it could become coercive when conibined with other facts. A father's importunities and the threat of losing an inheritance that was "as if owed to a daughter" were both regarded as coercive. ${ }^{187}$ Furthermore, the "steady inan" rule did not entail the absurd conclusion, urged by counsel, that only such fear as would coerce a steady male would invalidate Antonia's consent. Instead the standard to be used was the fear which would have affected a "steady women" of her "quality"- the fear which would have affected a motherless girl of the nobility. ${ }^{188}$ As to the sufficiency of the proof, Ludovisi held that requirements should be relaxed in proving parental coercion because of the inherent difficulties in estabhishing such a claim. ${ }^{189}$

The Marquis' counsel next argued that Antonia had given subsequent consent after her fear had been "purged." The Rota, however, refused to hear evidence on this point because the Tridentine form had not been observed in giving the subsequent consent. The older authorities required that this form be observed where the original consent was coerced, and so the court judged despite the contrary opimion of "moderns from Córdoba."190 The Sacred Congregation of the Council had ruled that if something essential had been lacking in the first ceremony, Trent required a whole new ceremony. Nothing could be more essential than consent, and if consent was impaired by coercion, the ceremony

185. Decisiones coram A. Ludovisio 387 (1622).

186. Id. at 414 .

187. Id. at 387 .

188. Id.

189. Id. at 414 .

190. Id. at 435 . 
had to be repeated. Then with a final bow to the leading "modern of Córdoba," Ludovisi said that "all scruple" was removed in this case because the coercion was public-so public that it was observed by the officiating priest- "and so there is followed Tomás Sánchez."101

The opinions in this case by an auditor of great prestige were a treasury of citations for Charles. Every major point he would have to make was covered by them in a way favorable to him. True, the facts could be distinguished, but, in outline, the law of the case was the law he wanted to rule his own.

Venice, May 25, 1622, ${ }^{192}$ could be cited as contrary authority. This was an opinion by Matteo Buratto, an auditor who, though he never becaine Pope, was still highly regarded for his knowledge of the law. A maternal aunt claimed that her niece Cecilia had been coerced into marriage by her father. Buratto, upholding the validity of the marriage, followed the path marked by Sánchez. Reverential fear of a parent did not itself amount to coercion. Citing Sánchez, Buratto added, "No love or counsel is superior to parental love or counsel."103 If this superior love is to be shown to have been coercive, the fear a parent generated must be proved "not in general but with qualities and circamstances."194 Sweepingly, he departed from Sánchez to fortify his conclusion by stating as a general principle, "Any force or suspicion of fear is excluded by the subsequent coupling and consummation."195

That the suit was by the aunt, not the wife; that Cecilia's view of the facts was not given; that no evidence on marital affection or its absence was stated in relation to "the subsequent coupling"-all of these factors made the case distinguishable from Charles'. Still, if Buratto's unqualified statement on the effect of subsequent intercourse was followed, Charles' case was hopeless. Furthermore, Buratto's basic view that a parent brought love and prudence to the choice of his child's mate was found in Sánchez and the society at large and einbodied a kind of presumption that Charles' lawyers would have to overcome with facts.

Coimbria, December 19, 1614, ${ }^{196}$ also decided by Buratto, provided almost the converse of coercion by parents-the coercion of a mother's suitor by her sons. Its relevance to Charles' case was that it was the seventeenth century paradigm of a fear case-a fear case that involved no grave challenge to social convention or parental authority,

191. Id., citing $1 \mathrm{~T}$. SANCHEZ, supra note $132,2.37 .11$.

192. 2 Decisiones coram M. Buratto 308 (1637).

193. Id.

194. Id.

195. Id.

196. 1 Decisiones coram M. Buratto 116 (1637). 
a fear case close to the situation of extreme physical peril dealt with by Alexander III in the decretal Veniens. ${ }^{197}$ Brutally, Coimbria underlined the difference between the case the law easily admitted and the kind of case Charles presented. A nobleinan, Emanuele, had been courting Bianca, a noblewoman twice widowed, rich, older than her lover, and the mother of grown children. Bianca expected the affair to turn into marriage and was disappointed when Emanuele procrastinated. Her two sons and her son-in-law shared her disappomtment. One night, Bianca called Emanuele to her country villa. By pre-arrangement, Emanuele, naked in bed with Bianca, was surprised by the boys and their attendants, armed with guns and swords. Bianca's parish priest was summoned in the middle of the night on the pretext that his parishioner was sick and wanted to confess. Once arrived, the priest was forced to stay, and in his presence Emanuele was forthwith married to Bianca. In the morning Emanuele escaped and with a sick heart immediately protested to the Bishop of Coimbra and the authorities, never returning to his new spouse. Armed force, surprise at night, immediate withdrawal by the coerced spouse offered a model of coerced marriage strikingly different from the situation of Charles and Nicole. Buratto invalidated the inarriage.

Coimbria, however, was not witlout its complication: Buratto found that Emanuele and Bianca were betrothed, and Bianca's counsel pressed for judicial enforcement of the betrothal. ${ }^{198}$ The court recognized that Emanuele had a moral duty to carry out his promise so that fear inflicted to this end would be "just" if inflicted by a court rather than by armed nien at night. It also recognized that there were circumstances which excused performance of a promise to marry. Such circumstances existed here: the forced inarriage itself and the prolonged hitigation. Fulfillment of the betrothal was not ordered. ${ }^{199}$

The final result reached in Coimbria was useful to Charles, even if the basic contrast of facts was glaring. In agreement with Sánchez, Buratto had refused to identify a right to have a duty enforced with a right to use all possible coercion. If Charles had had a duty to obey his father, as Emanuele had had a duty to inarry his betrothed, circumstances might still be shown which nade performance of the duty a submission to unjustified force.

Toul, November 7, 1617, ${ }^{200}$ still another opinion by Buratto, provided Charles with a valuable precedent in the analogous area of coerced religious profession. René, a 14-year-old boy from Lorraine, had

197. X 4.1.13. See text accompanying note 111 supra.

198. 1 Decisiones coram M. Buratto at 200, 273.

199. Id. at 380.

200. 1 Decisiones coram M. Buratto 285 (1637). 
been sent by his father from his home in Toul to Malta, there to inake profession as a knight. René spent his time in Italy, wasted his father's money, and returned to his father's castle without ever having been to Malta. His father expelled him from the castle, threatened him with total disinheritance, and requested family friends not to take him in. René lived in a hut on the castle grounds fed by pitying servants. After a few days of this treatment he capitulated and consented to do his father's will by becoming a knight.

In an analysis whose spirit was that of Sánchez, Buratto weighed the facts. Less fear was needed to be coercive when the fear was linked with the reverence owed a father and when the emotion was experienced by a boy, as the standard phrase even then had it, "of tender years." Above all, the threat of the loss of all his property was coercive. Such a threat, as Sánchez had already observed, could imduce fear in a steady man. Buratto found a "fearful and violent" and therefore invalid profession as a knight had been made.

Sueh a decision im the field of religious profession was of the greatest relevance because of the recognized parallel between profession and marriage. In solemnity, in absolute commitment, and in free dedication, the utterance of vows to God was like consenting to take a person as spouse. The ceremony of profession even used some of the symbols of marriage. Profession consisted of promises made under oath to God rather than promises made to a mere human being. But marriage, its indissoluble bond a symbol of Christ and the Church, was also a type of faithful commitment to God. The Council of Trent had seen the danger of coercion in religious profession and set up procedures to prevent abuses as to girls. ${ }^{201}$ No similar step had been taken to safeguard marriage. Yet if coercion invalidated one, so must coercion invalidate the other. Buratto specifically drew the parallel: "As marriage done by fear is not valid, so neither is profession, which is equated to it and is a certain spiritual marriage." ${ }^{202}$ The cases of coercion in religious profession and marriage influenced each other.

If case law of the past lialf century were used as a guide for prediction, these four cases indicated that Charles might overcome the presumption that a parent's love and counsel were for the best. If Venice represented a regression from liberality on reverential fear and Coimbria was to be the norm of coercion cases, Charles' way was hard. Yet Toul offered good analogy and hope. If the case law was read in the wider perspective afforded by Sánchez, there was enough in the facts

201. De reformatione monialium, ch. 2 (Nov. 20, 1563), 9 ConcILIUM TRIDENTINUM 510 (Societas Goerresiana ed. 1965).

202. Toul, November 7, 1617, 1 Decisiones coram M. Buratto 285 (1637). 
to make worthwhile a chance on hitigating. If the Rota could be persuaded to accept Seville as a model, Charles' case was almost made.

\section{IV}

\section{IN THE ROTA}

\section{A. The Court}

The Sacred Roman Rota was, in the words of Pius IV, the tribunal where "the more serious cases of all the Christian faithful may be known and decided."203 Its jurisdiction was worldwide, although the bulk of its business came from Italy. It handled a large variety of ecclesiastical conflicts and a quantity of property disputes, both ecclesiastical and secular. Marriage cases were less than five per cent of its load.

Twelve men made up the Rota. The semior man was the Dean, who enjoyed particular perquisites and responsibilities. Otherwise the auditors were equal. The Rota was a collegial body. Its judgments were announced as those of "the Lords." Each case was, however, assigned to a panel of four, of which one member was the ponens or judge-reporter. He issued all opinions in the case under his own name, but without the vote of his three coauditors he could not give definitive judgment or other "prejudicial rulings."204 Despite this restriction, the ponens played a dominant role in shaping any decision.

Each auditor had one or two "auditors of the studio," or law clerks, drawn from the junior bar and "distinguished for birth, talent, and learning." 205 Like law clerks in American higher courts today, these men were on the first rung of a career. They would move on to becoine advocates in the Rota or auditors in a nunciature abroad. Ultimately, they might be raised to the Rota itself. At this junior stage they provided the research assistance indispensable to a learned court.

Auditors of the Holy Roman Rota were appointed by the Pope. They were not charged for the appointinent. ${ }^{206}$ Papal discretion in choosing auditors, however, was restricted by the Rota's international character. Beginning with concessions made to the Kings of Aragon and

203. Pius IV, supra note 109 , at 155 .

204. Id.

205. J. EMERIx, supra note 107, at 127.

206. In this respect the Rota was distinguished from many other curial offices which were used to raise public revenue. Places in the Signature of Grace and Justice were regularly sold, although this body performed judicial fuuctious. Even the cardinalate had a price, although appointmeuts to it were supposed to be based on merit and the Pope might waive the fee. The Rota stood with the principal congregations of the Curia as exempt from this undignified commerce. See G. DE LuCA, Tractatus DE OFFICIS VENALIBUS ROMANE CURIAE passim (1735). 
Castille, a practice had grown of conceding rotal nominations to particular states. In 1640 there were two Spanish seats (Aragon and Castille each having one), a seat for the Holy Roman Emperor, one for France, one for Milan, one for Venice, one for Tuscany, one for Ferrara, and one for Bologna (papal territory, but entitled to special consideration as the seat of the university center of canon law). ${ }^{207}$ Three seats were left completely open to papal choice. The prevailing custom gave the Rota both the weakness and the strength of a modern international court. While the appointees thought of themselves, to a considerable extent, as representing their areas, the cosmopolitan nature of the body was much to its benefit.

Class as well as country limited eligibility. Auditors were customarily chosen from the richer and the nobler families; a person not of noble birth was either made noble by the Pope or formally dispensed from the requirement. There was an additional requirement that an appointee have an income outside his salary. ${ }^{208}$ These considerations, in theory at any rate, were not designed to perpetuate upper class control of the judiciary, but to assure honesty in the judicial office.

Apart from these limitations and the usual pressures of politics, friends, and favorites, selection to the Rota was based on merit. At least coinpetence was sought, and often the Popes found first-rate lawyers. The meritocratic aspect of selection was symbolized by a rite: A nomimee to the Rota had to conduct an argument before the assembled incumbents of the tribunal. This public trial was followed by a second private session before the body. The candidate was interrogated by each of the auditors in turn, front the most recent to the most senior up to the Dean. The Dean dispensed himself from questions and merely gave the correct answers to the questions the candidate had been attempting to answer. ${ }^{209}$ This ritual was designed to deter the presumptuous rather than to detect the incompetent, for it occurred after the Pope had already made the nomination. Like other initiations, this novitiatethe term from religious life was actually used-functioned primcipally to create an esprit de corps among those who had undergone it.

Once an auditor was seated he had both a respected office and a substantial income, ${ }^{210}$ but these did not exhaust the rewards of rotal

207. 1 E. Cerrchiard, supra note 93 , at $61-65$.

208. Id. at 78 .

209. Id. at $95-98$.

210. Each auditor received a salary of 600 scudi ( 1 scudo $=97$ cents) per year from the papal treasury, the Apostolic Chamber. In lieu of an ancient tax exemption, each received an additional 50 scudi annually from the papal tax collector. The Pope gave each auditor a yearly bonus of 100 scudi (200 scudi to the Dean), and whenever a Pope died, the auditors received 200 scudi apiece. J. EMERIX, supra note 107, at 160-65. By comparison, the best-paid professor of canon law at the Sapienza earned 
appointment. An auditorship was an excellent way to acquire experience in the Church system. By custom, all auditors becaine chaplains to the Pope; the Dean and next two senior men were voting participants in the Congregation of Rites on the canonization of saints; one auditor was named consultor to the Inquisition; the Dean was made canomical examiner for the Congregation for the Examination of Bishops; one auditor was designated lieutenant to the Chancellor of the University of the Sapienza; and all the auditors collectively were made administrator of a poor boys' school, the Nazareth. ${ }^{211}$ Auditors were also drawn on for work by the Secretariat of State. They lived, on the whole, in neither monastic nor judicial isolation. They were enmeshed in the working of the administrative business of the Curia, although their primary job was judicial.

Experience like this was preparation for even higher position in the Church, and to experience was jomed the imdispensable requirenient for promotion-visibility to those with power to promote. As a consequence, the prestige of the Rota rested not only on the dignity of its role and the quality of its performance but on the successful careers of its members. From the beginning of the pontificate of Julius III in 1550 to the end of the regime of Innocent $X$ in 1654, 91 inen became auditors. Of these four became Pope, 24 inore became cardinals, and 25 became bishops. In all, over lalf advanced in rank and almost onethird entered the highest circle of the Curia. ${ }^{212}$

The Rota was indeed a chief source of the supreme leadership in the Churcl's monarchical government. The two main Roman Cathohic tribunals, the Signature and the Rota, were, in the critical metaphor of Cardinal De Luca, "so many Trojan horses from which issue Sovereign Pontiffs."213 Nothing could better demonstrate the extent to which the Curia viewed the Church as legal system than the success of these men of law. Nothing could better emphasize the crucial effects of rotal litigation upon the government of the Church. The lessons learned in such litigation were the education of the ruling elite.

\section{B. The Bar}

Like the modern English bar, whose ancestral relative it was, the Rota bar was divided imto "advocates" and "procurators."214 Advocates, like Enghish barristers, presented the case to the court and were

\footnotetext{
but 420 scudi per year. The pay scale of lesser professors ran from 250 down to 75 scudi per annum. 3 F. ReNAzZI, Storia DELL UnIVERSITA DEGLI STUDI DI ROMa DETTA COMMUNEMENTE LA SAPIENZA 295 (1805).

211. J. EMERIX, supra note 107, at 141-49, 153-66, 166.

212. 2 E. CerchIARI, supra note 93, at 327-29.

213. G. De LUCA, supra note $206,4.11$.

214. See J. EMERIX, supra note 107, at 129-33.
} 
valued for their knowledge of the law and their persuasive talent. Procurators, like English solicitors, arranged conferences between the parties and advocates, briefed the advocates, and prepared the articles or topics on which the witnesses would be examined. The procurators performed the crucial task of excerpting parts from the record to go into their side's summarium, and if their client won they drafted the judgment for the court. Less honored than the advocates, as managers of the case they carried out tasks requiring at least equal legal skill.

Practitioners were usually in minor orders, sometimes priests, occasionally laymen. Decretal law limited priests to practicing law only on behalf of themselves, the Church, or the poor, ${ }^{215}$ but papal dispensations were routinely given the secular clergy to authorize them to engage more generally in practice in the ecclesiastical courts, and a cleric who knew the civil law could usually be dispensed to obtain a "decent livelihood" in civil litigation. ${ }^{216}$ While laymen were not unwelcome-the famous auditor Buratto was a layman-orders were necessary if a lawyer was to pursue his career to the highest ranks.

Within the two mam divisions of the bar there was a hierarchy that did not depend on clerical status. At the top was the College of Consistorial Advocates, a body of twelve "fully proved in birth, morals, and doctrine," and distinguished on public occasions by clothes that they alone could wear. Consistorial Advocates were appointed by the Pope and were subjected to examination by the Rota before they could assume their title. Collegially the twelve constituted the governing board of the Sapienza and thus had supervision of the school of most Roman canonists. From the ranks of the College were drawn auditors of the Rota and bislops, and some Consistorial Advocates became, in season, cardinals and Popes. Membership in the body was the highest recognition a practising canon lawyer could receive.

"Advocate" itself, as well as "Consistorial Advocate," was a title which could not be assumed at will. After some years of trial, an aspirant was awarded the designation "Advocate of the Holy Roman Rota" by action of the Dean after examination. ${ }^{217}$

Procurators might be admitted "to write" in the Rota and so advance to the rank of advocate, but often they did not desire this promotion. They had their own hierarcly, in which precedence and privilege was held by the 24 members of the College of Procurators. Below the procurators were agents and solicitors, who acted as the secretaries for the procurators in actually writing out the papers used in the case.

215. X 37.1-.3.

216. 2 Benedict XIV, De Synodo diocesana 13.10 .12 (1764).

217. 3 E. CERCHIARI, supra note 93 , at 449 . 


\section{Rotal Procedure}

The first step in the presentation of a case before the Rota was the preparation of the articles, a list of topics on which counsel hoped to examine the witnesses. The articles gave the court its first view of what the parties thought the issues were and what they intended to prove. The court, in turn, ruled on the articles by determining the topics on which testimony could be taken, necessarily giving its first impression of the case. The court, through its ponens, then issued remissorial letters, which were commissions to various Church authorities outside Rome to hear testimony on the approved topics. Answers by the witnesses on these topics were then taken down, not verbatim, but in substance. The procurator then culled the record for testimony favorable to his side and, incorporating docunnents selected to establish his case, produced a summarium. The parties' summaria functioned as the record, each side referring to its own summarium for the facts. When testimony was identified in the briefs, reference was made to the appropriate section in the summarium. Its composition was frankly partisan, although the material itself was faithfully taken from the hearings, and normally each side would submit a summarium. The procurator had to be fully in command of the case to omit nothing im his summarium essential to his claim, for the judges relied on the summaria for their understanding of the facts.

The summarium acted as a kind of filter for facts and emotions. The auditors ordinarily did not see the witnesses themselves. Furthermore, the testimony reported in the summarium was not taken down verbatim and was translated from the vernacular into Latin. This distancing process was consistent with the other chief difference between rotal procedure and its English counterpart: the Rota's emphasis on argument by written brief. Since the time of Paul III, it had been agreed by the bar and approved by the Pope and Curia that argument would be in writing. ${ }^{218}$ The reason for this rule is obscure. Perhaps it was a combination of practical motivation (a lawyer's compensation was based on the number of written documents), the academic sense of the dignity of the written word, and the experience of oral argument as too often noisy shouting. The spread of printing favored the practice, althougl not all rotal briefs were printed. ${ }^{219}$

218. L. Gomes, Commentari in iudiciales regulas Cancellariae 1.3 (1575). According to Goines, the old practice was to have only written argument, "following the counsel of Clement IV." This practice was abandoned under Alexander VI due to "the cupidity of some of the advocates." Gomes gives no reason for the bar unanimously agreeing to return to the old practice under Paul III.

219. A happy by-product of this practice for legal historians is thet the files of the Rota are jammed with law briefs dating back to the seventeenth century. This is in 
In accordance with theory, advocates were admitted to the Rota bar not to speak, but "to write." This theory, however, was softened by practice, for advocates were not without an opportunity to address auditors orally and to present in person the considerations they knew would be most striking. The day after the submission of briefs to the ponens, it was customary for the advocates, the procurators, and the litigants themselves or their gentlemen to appear at the ponens' residence and argue the case. Consistorial Advocates had a place of precedence at these presentations which was envied by those not so favored.20 $^{220}$ Oral argument was repeated the following day at the residence of the ponens' principal assistant. This procedure was praised in Emerix's seventeenth century handbook because "the procurators so clearly and distinctly set out the facts, and the advocates so learnedly and wisely confirm with laws and reasons, that the auditors who attentively hear them and effectively suggest the difficulties they feel, reach a resolution, when the written material arrives, with much less-and sometimes very little-labor . . .."221

The Rota rendered its opinion in the presence of the entire body of twelve, seated at a round table, hearing the case presented by the ponens. However, only the four auditors seated to ponens' left-his co-responsales - were entitled to vote. If there was a tie, the case was put over for another session and, if the tie persisted, two nore auditors were added. The process continued until a majority could be found.

The Rota's opmions and judgments were not identical. An opinion was the advice of the auditors, prepared by the ponens, and sent to the parties before final judgment was entered. The parties were then given an opportunity to offer further evidence or argument in conforination or rebuttal of the views expressed in the opimion. "[A]nd thus it is that many times, when the matter is better elucidated, the Rota withdraws froin what it had said."222 When final judgment is later rendered, the decision is said to be "executed."

\section{Skirmish and Scandal-The Initial Proceedings}

Of the twelve auditors who constituted the Rota when Charles' case began in 1646, all but two had been appointed by Urban VIII. ${ }^{223}$ Francesco Maria Ghisheri, appointed in 1627 and second in seniority

contrast to England, where leavy reliance was placed on the lawyers' oral argument.

220. E. CerchiarI, supra note 93 , at 466 .

221. J. EMERIX, supra note 107, at 91-92.

222. Id. at 98.

223. See 2 E. Cerchiari, supra note 93, at 145-68. 
only to the Dean, was selected by Innocent $\mathrm{X}$ to serve as ponens. Ghislieri occupied the prestigious Bolognese seat, previously held by the learned Matteo Buratto and by the later Pope, Alessandro Ludovisi. He came from a family with a long line of distinguished canonists, and in 20 years of service had himself become known for outstanding scliolarship. 224

In spring of 1648 the tribunal, per Ghisheri, made its first rulings in Charles' case, on the remissorial letters. ${ }^{225}$ The Rota noted that Nicole would attempt to prove that the marriage was contracted by new expressions of consent emitted after the arrival of the papal dispensation from consanguinity. It observed further that a marriage might be proved by witnesses as well as by the parish record book required by Trent; ${ }^{226}$ that the palace chapel of St. George was exempt from the Bishop's administrative, but not from his pastoral, jurisdiction; ${ }^{227}$ and that long cohabitation might be a defense against a claim of coercion. All of these observations pointed in Nicole's favor. The sole, shight concession made to Charles was to admit Béatrice as a party to the case to defend her interest as it might appear.

Ghislieri had every expectation of remaining in charge of the litigation as ponens. But in the summer of 1648, rumors circulated in Rome that the Rota could be bought. Touched at a very sensitive point, Innocent $\mathrm{X}$ asked the Dean to investigate. On August 3, 1648, the Dean assembled all the members at the Nazareth School on the pretext of discharging their supervisory administration over it and, once assembled, he proposed that they determine for themselves where the guilt lay. One by one the auditors left the room and were discussed by their colleagues. Hearsay pointed to a single man-Francesco Maria Ghislieri. While serving as ponens he was reported to have been paid 500 scudi by Cardinal Montalto in one case, 1500 scudi by Primce Borghese in another, 400 scudi by the Princess Verula in yet a third, and 2000 scudi in the Robigni partnership hitigation. In all, he was

224. Id. at 146.

225. Toul, June 26, 1648, 10 Decisionum recentiorum 380 (1716). Two years had passed since the issuance of the papal rescript (see text accompanying note 96 supra), but the spring rulings came less than a year after the failure of negotiations (see text following note 98 supra), and the lawyers had had much preliminary work to do in the preparation of their articles.

226. See text accompanying note 119 supra and note 294 infra.

227. One of Cheminot's grounds for arguing the invahdity of Charles' marriage (see text accompanying note 27 supra) was that the Bishop of Toul, who officiated at the wedding (see text accompanying note 17 supra), could not be considered the parish priest or delegate required by the Council of Trent. This argument was based in part on the fact that the chapel in which the wedding took place was exempted from the Bishop's administrative jurisdiction. For the final disposition of this argument, see text following note 294 infra. 
found to have received illicit payments amounting to six times his legitimate annual income as an auditor. ${ }^{228}$

Rules on gifts to auditors had been emphatically laid down by the reform bulls, In throno justitiae ${ }^{229}$ of Pius IV and Universi agri Dominica $^{230}$ of Paul V. Ghislieri had no chance of mamtaining that he was within the rules, and he apparently could not deny the allegations. Instead he pleaded with his colleagues to spare his reputation, the reputation of his family, and the reputation of Bologna. ${ }^{231}$ His plea was, in measure, heeded. No public trial, no public denunciation followed the scene at the Nazareth School. Ghislieri was removed from office by being made Bishop of Terracina, a small seacoast town and a diocese with an income somewhat greater than his Rota salary. ${ }^{232}$ The kind of treatment accorded Ghislieri was that given the member of an established governmental ehte-say a high civil servant in the British Foreign Office-who has bungled badly. ${ }^{233}$ Really high office that might liave been his was forever denied him. Ghisheri could not be Dean of the Sacred Roman Rota, Archbishop of Bologna, cardinalall rewards within his grasp after 20 years of service. He was sent off to a minor post, to exile from the center of power. He was not tried as a common criminal, for the scandal would have hurt the institution, ${ }^{234}$ and, besides, the victims of his bad behavior were those outside

228. See 2 E. Cerchiari, supra note 93, at 147-50.

229. Pius IV, supra note 109 , at 157.

230. Paul V, supra note 109 , at 69 . These two bulls permitted litigants to make small payments, sportulae, to an auditor. These sportulae were a kind of court fee, public, recognized by law, aud regulated in the reform bulls. In 1641, the Rota decided that these paymeuts be pooled, so that they could not be considered as given to an individual auditor. The sportulae totalled about 50 scudi a year for each auditor. J. EMERIX, supra note 107, at 108 . With the exception of these small payments and quantities of food or drink that could be consumed within three days, gifts to auditors, their families, or their servants were forbidden.

231. 2 E. Cerchiari, supra note 93 , at 151.

232. Ghislieri was later able to manage something of a comeback. In 1644 , under Alexander VII, he was transferred from Terracina to Imola, a more substantial town with an income of about 7000 scudi. 4 HIERARCHIA CATHOLICA 209, 311 (1935). This income, combined witl his papal pension of 1000 scudi, was ten times his official Rota salary.

233. Ghislieri's unostentatious removal may be profitably contrasted with the case of Francesco Canonici, Under-datary of Innocent $X$ and inuch esteemed by the Pope. In the performance of his office lie was accused of forging papal documents, obtaining the Pope's signature by fraud, and selling the documents for personal profit. Canonici was expeditiously tried, convicted, and executed. 3 E. CerchIARI, supra note 93, at 43-44.

234. Innocent X's judgment in this regard is open to serious question. The seventeenth century Rota's reputation was not above challenge. During the next pontificate, a Rota official of 28 years' service presented Alexander VII a list of abuses in the court whicli imcluded bribetaking by some auditors. $31 \mathrm{~L}$. VON PASTOR, History OF THE Popes 28-29 (E. Graf transl. 1957). In 1663, Cardinal Spado drew the saine Pope's attention to the improper mtervention of cardinals and other curialists on behalf of litigauts in the Rota. Id. at 29. Perhaps if Innocent $\mathrm{X}$ had made an example 
the center. Litigants, like Charles and Nicole, were left to draw what inferences they liked as to why Ghislieri was no longer responsible for their affairs.

No breath of bribetaking had occurred in Charles' case, but when Ghislieri abruptly left in the summer of 1648 , it had to be assigned to someone else. Innocent $\mathrm{X}$ made the choice. He gave the case to the man brought from Bologna as Ghislieri's successor, Antonio Albergati. ${ }^{235}$

As the inheritor of the Bologna seat, Albergati was the logical choice for the case. He was also the Pope's nephew. Waiting for Albergati from August to March may have caused delay for the litigants, but such delays counted hittle against the papal interest in a nephew taking charge of a big case. After the talk of corruption, Innocent $X$ wanted someone he could trust-trust to do what he was told and to be loyal, discreet, and honest. Albergati was an arclipriest in Bologna. Already quite rich, he had a degree in civil and canon law from Padua; and he was a good man. He lived long enough to become dean of the Rota in 1669 and to die in office in 1686. His success was owed to longevity, not erudition.

In 1649 he was still learning the ropes, and his intellectual abilities were not outstanding. His uncle the Pope advised him to be diligent imitating the other auditors "and for some space of time to pretend nothing else but to learn." ${ }^{236}$ In handling Charles' case at this stage of his career he must have taken orders from his uncle on major matters and relied on his assistants and the parties' lawyers to marshall the facts and law for him. Assistants and lawyers did not let him down.

During the next four years the witnesses were examined. The lawyers' briefs were prepared. The parties waited.

The parties did not wait wholly passively. Shortly after the unfavorable rulings of 1648, Cliarles and Béatrice inust have come together, for Béatrice, then aged 35, again becaine pregnant. Their first child, born in 1637, had died. Their second, born in late 1639, turned out to be a girl, Anne. The child now conceived was a male heir, Charles-Henri, born April 17, 1649.237

Thereafter Charles and Béatrice appear to have lived apart for 28 months, practically from the date of the birth. ${ }^{238}$ The cause of this

of Ghislieri, a purer atmosphere would have been fostered. As it turned out, Ghislieri was to be the ouly auditor in history ever to have been even mildly censured for bribetaking. 2 E. CERCHIARI, supra note 93, at 330.

235. 2 E. CERCHIARI, supra note 93 , at 169.

236. Id.

237. Bonnard, supra note 2, 71 SocIETE 264.

238. 3 A. CALMET, supra note 2, col. 475. 
separation is uncertain. Charles may have harbored doubts about the child's paternity. After all, Béatrice, on her own, had lived a gay life, courted by Prince Charles Stuart of England and Prince Radziwill of Poland. ${ }^{239}$ Or, it may have been because Charles had achieved his objective and no longer needed Béatrice. Again, Charles may have thought that a real "canonical separation" was essential if his case was to go ahead in the Rota. At all events, the separation occurred and had the effect of embittering the relations between Charles and Béatrice. Reports of her flirtations reached him in Brussels and were enlarged upon by his own relatives, who were anxious to discredit her. Charles was heard to say that if his marriage case was ever resolved in his favor, Béatrice might expect "to be chastised with light irons." On November 19, 1652, he went to her in Antwerp, upbraided her coldly, and removed from her possession all the jewels he could claim as his. He returned to Brussels the next day, demonstrating that his visit had no hidden motive of enjoying her companionship for any length of time. ${ }^{240}$

In the fall of 1652, the coolness between Charles and Béatrice made Charles' family believe that it was time to have judgment pronounced on the marriage. Nicolas-François took the initiative in Rome, in urging the Pope to act. Nicolas-François and his two sons after him stood as clainiants to Lorraine if his brother Charles died without lawful issue. He was at the court in Vienna and in good standing with the Emperor. Aunt Eleanor, the Empress, joined in his appeal to the Pope, working through the Archbishop of Rhodes, one of the Gonzague family, to the sanie end. Another Gonzague relative, the Queen of Poland, used Cardinal des Ursins to urge actions. Still the Pope hesitated, fearmg that Charles would not return to Nicole and that a decision would provoke him to scandalous disobedience.

Marguerite, Duchess of Orleans, another of Charles' younger sisters who like to manage her brother's business, tried to get Charles to send a written promise to the Pope that he would accept and obey any any decision of the Rota. So persuasive was Marguerite that Charles accepted her draft of the promise, merely changing the "pretended wife" of her text to "Madaune Béatrice" when referring to his former love. Nicolas-François, the Emperor, and the princess of the House of Lorraine then jointly asked the Pope to have the case decided. ${ }^{241}$

239. P. MARECHAL, supra note 21 , at 200.

240. 3 A. CALMET, supra note 2, cols. 475-76.

241. Id. col. 477. 


\section{E. Presentation of the Case}

\section{For Charles}

Charles was not content simply to have his case presented by one or two well qualified attorneys. Following the custoin of wealthy noblemen involved in important cases, he enlisted a veritable army of highly skilled counsel. Carlo Emanuele Vizziani and V. de Vermiglioli, both Consistorial Advocates, lreaded the team. Vizziani was at the peak of his powers, recently elevated to the consistorial rank by Innocent X. He was well regarded by his colleagues, who in 1658 elected him rector of the Sapienza. ${ }^{242}$ Bolognese, he could be expected to have rapport with Albergati. Vermiglioli, in contrast, seems to have been added to the petitioner's team chiefly for the value of his name. A Perugian who liad served in Rome as auditor of the prelate Serlupo and then had had a sinecure as "conservator of the Capitol," he was the author of Consilia criminalia ad defensionem in Romana curia, pubhished in Roine in 1651.243 Eighty years old when he appeared as Charles' counsel, he filed but a meager two-page brief on his behalf.

Of central importance to Charles was Celio Piccolomini. Although not a Consistorial Advocate, Piccolomini was in his prime as a lawyer. A meinber of the great Piccolomini family of Siena, which had produced Pius $\Pi$, he was a graduate of the law course at Siena. He liad been locumtenens of an auditorship in the Apostolic Cliamber, and he was now nicely beneficed as a canon of St. Peter's. When he undertook Charles' case he was midway in his career. In 1656, Alexander VII was to name him Nuncio to France. A cardinal in 1664, he came home to Siena in 1671 to rule for twelve years as Archbishop, a not unpleasant role in old age for an experienced diplomat and curialist. As his history suggests, he was a man of talent, energy, and luck; a man to have as one's advocate. ${ }^{244}$

Rounding out the team were an advocate and two younger lawyers. The advocate, Hercule Ronconi, was in sufficiently good standing in the Curia to act as a censor of books for the Master of the Apostolic Palace in 1646. ${ }^{245}$ The young lawyers were Prospero Bottimi and Ar-

242. 31 L. von Pastor, supra note 234 , at $273 ; 3$ F. ReNazZn, supra note 210 , at 202 .

243. 3 J. von Schulte, Gesichte der Quellen und Literatur des CanonISCHEN RECHTS 469 (1880).

244. See 4 Hierchia catholica 126 (1935); 5 id. at 353 (1952).

245. See note preceding imprimatur to S. ZACCHIA, LuCUBRATIONES AD GallesumM DE OBLIGATIONE CAMERALI (1947). Roconi inay well have been related to Cristoforo Roconi, a 67 year-old lawyer from Faenza who was a consultor of the Sacred Penitentiary and a referee in the Signature of Justice under Innocent X. See 2 SussmI PER LA CONSULTAZIONE DELL'ARCHIVO VATICANO 315 (1931). 
mindo Ricci. Bottini, only 29 in 1650 , was at the beginning of his professional life and was to have a very respectable career in the Curia. By 1675 he was a Consistorial Advocate and so at the summit of his profession. By then, he was also a referee in the Signature of Justice, a canon of St. Peter's, and abbot of St. Jerone in his home town of Lucca. In that year the Consistorial College chose him as rector of the Sapienza, a post where "he carried out many public improvements with great éclat." 248 In that same happy year he became titular archbishop of Myra. He continued a vigorous practice, filling the role of chief counsel for the Apostolic Chamber in a famous Rota case in $1680 .^{247}$

Armindo Ricci, not yet admitted as an advocate, was a lawyer from the Marches, from the village of Monte San Martino near Fermo. He had reached the ladder of preferment but had not yet begun its ascent. Under Alexander VII he became Under-Datary, and in 1669, because of the incumbent's age, he became acting Datary. Through papal largesse he died a ricli man, leaving his fortune to support scholars and to establish a charitable foundation for children in his home village. ${ }^{248}$

Cliarles, in short, had working for him a future cardinal-archbishop, a future papal datary, two future rectors of the Sapienza, and two veterans of curial practice-a balanced team, it might be observed, strong in youthful energies and not lacking in connections or reputation.

Charles' summarium concentrated on coercion and on the absence of subsequent consent. The quarrel between Charles' father, François, and Duke Henri II was amply established. The testimony showed that François stood to lose all chance of the dukedom for himself or his heirs unless he somehow achieved reconciliation with his brother. ${ }^{240}$ Chalabré, Charles' chamberlam and principal witness, testified that he liad heard it said that François would put Charles out of the house, deprive him of all his goods, and reduce him to a state of misery if he did not agree to the marriage. He reported personally seeing Charles leave his father's bedroom weeping and complaining of these threats. ${ }^{250}$ However, there were no eyewitnesses to the actnal threats save Charles

246. 3 F. RENAZZI, supra note 210 , at 203.

247. See 2 SUSSIDI PER la CONSULTAZIONe DELl'Archivo Vaticano 325 (1931). The case arose from the Pope's suppression of the College of Apostolic Secretaries. Several of the Secretaries who had paid their predecessors to resign argued that the Pope should make restitution of these sums. Bottini successfully argued the Apostolic Chamber's position that it owed no restitution for money it never received. An account of this case appears in the appendix to G. DE LUCA, supra note 206.

248. 39 G. MORONI, DiZTONARIO dI ERUdIZIONE STORICO-ECCLESIASTICA 251 (1846); 40 id. at 312-14; 5 V. SpRETI, ENCIClopedia STORICO-NOBILIARE ITALIANA 683 (1932).

249. Summarium pro D. Carolo ff.299v-303v.

250. Id. f.291r. 
himself, and decretal law treated his testimony as open to exception when it told against the validity of his marriage. ${ }^{251}$ François' former valet, Walter Platel, had seen François threatening Charles in his study, but he had not heard his words. ${ }^{252}$ Nicolas Mareschal, another household servant, had heard François shout and seen Charles cry; he learned from the servants that father and son had been discussing the marriage, but did not hear the conversation itself. ${ }^{253}$ Chalabre and another witness said they heard François admit to "forcing" Charles to marry Nicole. ${ }^{254}$ Several other witnesses testified of François' violent nature, his maintenance of strict discipline over his children through their fear of him, and his propensity to bring his threats into execution. ${ }^{255}$

The summarium also contained evidence of Charles' lack of marital affection for Nicole. Before the wedding, witnesses testified, Charles would become upset at the sight of Nicole and refused to visit her. ${ }^{250}$ The morning after the second ceremony, the Countess of Tornielles visited the couple's bedroom. She testified that Charles and Nicole were in the same bed, but they were "sad and morose, with their faces turned froin each other." There were no signs that they "had treated each other with pledged love."257 Other witnesses testified that consummation was delayed for four months, ${ }^{258}$ and that Charles chose to live apart from Nicole for extended periods of time. ${ }^{259}$

Charles' summarium also contained evidence that Nicole was herself coerced into the marriage by her father. Witnesses testified that she was in love with her betrothed, Louis de Guise. ${ }^{260}$ Even after her marriage to Charles, Nicole still longed to go off with Louis, and her father had to forbid her seeing him. ${ }^{261}$ She "refused to love Charles,"262 and her father struck her and threatened her for refusing to consummate the marriage. ${ }^{263}$

The marriage contract was set out, revealing the terms of the settlement between Henri II and François: Nicole and Charles were to marry. Nicole was named "universal heir" of her father "in all his territories and possessions." The contract also contained contingent

251. E.g., X 4.13.5; X 4.18.4.

252. Summarium pro D. Carlo f.291v.

253. Id. f.292.

254. Id. ff.299v-300r.

255. Id. ff. $298-300$.

256. Id. ff. $294 \mathrm{v}-295 \mathrm{r}$.

257. Id. f.295r.

258. Id. f.297v.

259. Id. ff. $295 \mathrm{r}-298 \mathrm{r}$.

260. Id. f.301v.

261. Id. f.297v.

262. Id. f.296r.

263. Id. 
provisions "in order to keep the said states, lands, and signories in the proximate strips." 204

Charles' lawyers also introduced a surprise docuinent: a "protest" jointly executed by François and Charles five days before the signing of the inarriage contract. Witnessed by the Bishop of Toul, this careful legal document rejected in advance the clause naming Nicole universal heir and pressed their argument that only inales could inherit Lorraine. They further declared that in signing the inarriage contract they were responding to "force and coercion arising from the fear which can fall upon the steadiest inan." 265

Charles' briefs einphasized François' motives for coercing his son into marriage and his fearsoine nature, which made his threats all the more coercive. In addition, the threat of losing an inheritance that was his as a matter of right was argued to be coercive per se, citing Sánchez. ${ }^{268}$ Charles' case was likened to Seville, June 18, 1607, ${ }^{207}$ and Toul, November 7, 1617.268 Seville had decided the inajor points of Charles' case in his favor: threatened disinheritance, a severe father, pre- and post-nuptial sadness, and intent to inarry another (relevant to Charles' argument that Nicole was herself coerced) were all held evidentiary of coercion. Seville further held that subsequent consent to a coerced inarriage was valid only if accompanied by the Tridentine ceremony. Charles' counsel also pointed out the striking similarities between his case and Toul, the case of coerced religious profession: each involved an adolescent noble froin Toul characterized by soine self-rehiance; each involved an initial negative response to a father's demand for a lifelong commitment; each involved ultimate submission to a paternal threat of disinheritance.

Coercion established, counsel then argued that there was no valid subsequent consent to the marriage. Relying primarily on the Rota's decision in Seville and on Sánchez' analysis of private and public impediments, ${ }^{269}$ Charles' attorneys argued that the invalidating fear was a public impediment because provable by two witnesses, ${ }^{270}$ and, therefore, subsequent consent could not be validly given unless accompanied by the Tridentine ceremony. Since no such ceremony accompamied

264. Id. ff. $303 \mathrm{v}-305 \mathrm{r}$.

265. Id. f.303v.

266. $1 \mathrm{~T}$. SANCHEZ, supra note $132,4.5 .27$.

267. Decisiones coram A. Ludovisio 387 (1622), discussed in text accompanying notes 185-91 supra.

268. 1 Decisiones coram M. Buratto 285 (1637), discussed in text accompanying notes 200-02 supra.

269. See text accompanying notes $180-83$ supra.

270. Counsel were apparently relying on the hearsay testimony of Chalabre and others as proving coercion. See text accompanying notes $250,252-54$ supra. 
the acts alleged to constitute subsequent consent, those acts could not validate-or, more precisely, create anew-the marriage.

\section{For Nicole}

Like Clrarles, Nicole found six highly talented, if slightly less distinguished, attorneys to present her case. Paulo Boncampagni was distinguislied chiefly by belonging to the family of three canomists become Pope-Gregory XII, Gregory XV, and Alexander VII. Eusebio de Eusebii, a lawyer of about the same experience as Cliarles' Vizzari, was to become a Consistorial Advocate in 1653. ${ }^{271}$ Tomasso Balbani and Carlo Saracem appear never to have held a prominent office in the Curia. The two youngest men were, in the long run, to be most celebrated. Measured by their subsequent careers at least, they slightly outpointed Charles' young lawyers, Bottini and Ricci. Alessandro $\mathrm{Ca}$ prara graduated from Bologna with degrees in canon and civil law in 1647 and was ordamed in 1650. He became a Consistorial Advocate in 1662, auditor of the Apostolic Chamber in 1675, and finally auditor of the Rota in 1686, taking the Bolognese seat left vacant by Albergati's death. He lived to a ripe age, becoming acting Dean of the Rota and Regent of the Holy Penitentiary in 1646, leaving the Rota only to become a cardimal in $1706 .{ }^{272}$ The son of Bolognese nobles, he supplied the essential Bolognese element to the staff, and he made up for his inexperience by his energy. Alessandro Saracinelli was the junior man, about Ricci's age, and, like him, not yet admitted to the bar as an advocate. From a hill town close to Rome, Orvieto, his career paralleled Ricci's, but he preceded him as Under-Datary in the regime of Alexander VII. ${ }^{273}$

Nicole's summarium laid out evidence of the elements of a valid niarriage, slrowed the continuation both of the marriage and of Charles' affection for twelve years, and attempted to demonstrate the unreliability of Charles' witnesses. The wedding was proved not by the parish record book required by the Council of Trent, for it had not been kept, but by the testimony of witnesses who were in attendance. Proving the wedding was opportunity for disproving the presence of any sign of coercion. Festivity, gaiety, and joy had prevailed. Relatives, friends, and high ecclesiastics had beamed their pleasure. Warlike tournaments staged by François had saluted the couple. ${ }^{274}$ Only the acrostics, anagrams, and riddles of Pont-à-Mousson ${ }^{275}$ were omitted

271. 3 E. CERCHIARI, supra note 93 , at 383.

272. 2 id. at 198-99.

273. 39 G. MoronI, supra note 248 , at 251.

274. Summarium pro D. Nicole ff. $197 \mathrm{v}-198 \mathrm{v}$.

275. See text accompanying note 24 supra. 
from the picture of general rejoicing drawn by Nicole's summarium.

Consummation, the witnesses conceded, did not occur after the first ceremony of May 22. Father Dominic, the officiating priest, had claimed to have authority from the Pope to dispense from consanguinity viva voce, but it was deemed safer to postpone intercourse until a bull arrived in writing. In due course, the dispensation, dated May 25, 1621 , had come, and it was set out in full in the summarium. ${ }^{270}$ In it, Pope Gregory XV recognized that the cousins married in response to "the exhortations and persuasions" of Father Dominic, who had been specifically sent by Paul IV "to treat of a marriage of this kind." The Pope observed that the inarriage had been contracted and not consummated. The Pope declared that the marriage was "greatly useful to the public good." He granted the dispensation, requiring, however, the re-celebration of the marriage. Cautious, ample, a first-class piece of draftsinanship, the bull of dispensation was not only proof against attack-no lawyer thought it sensible to pursue Cheminot's charge that the dispensation was invalid ${ }^{277}$-but, beyond invuhierability, the bull read like a papal certification of the soundness of the marriage.

The great bull arrived on June 5,1621, and the second ceremony took place the next day, Trinity Sunday, before another crowd of distinguished guests. This second wedding, something of an anticlimax in popular appeal, was crucial canomically. Both Father de Lignaville, guardian of the palace chapel, and Bishop des Porcelets had been present, with the Bishop overruling de Lignaville and as "the pastor of pastors," officiating at the wedding. ${ }^{278}$

Nicole's advocates took care to show that the Tridentine form had been observed-a point never challenged by Charles' counsel. Their concentration on Trent reflected the knowledge that failure to ineet the requirements of form was the easiest basis to attack a marriage and that the courts examined the form with scrupulous regard for technicalities. Counsel knew the outline of Charles' case from the remissorial letters and articles, but they inust have wanted to shut off any questions which might be belatedly raised in argument.

Consummation was proved by hearsay and common report. Counsel for Nicole had the luck to present Charles' former first chamberlain, who spoke as a virtual eyewitness. He testified that he had seen Charles and Nicole in the saine bed "showing by their words and acts that they were very happy."278

Nicole's attorneys freely conceded that the marriage was arranged

276. Summarium pro D. Nicole f.198v.

277. See text accompanying note 27 supra.

278. Summarium pro D. Nicole ff.200r-201r.

279. Id. f.203r. 
to settle the dispute between Henri II and François. The marriage contract was set out in full, ${ }^{280}$ and no attempt was made to show that Charles and Nicole were in love at the time of the wedding. But they demed that this was evidence of coercion-after all, Charles had as great an interest as his father in assuring his family's dominion over Lorraine. Furthermore, they disputed Charles' characterization of his father. Thirty witnesses for Nicole testified that François was humane and mild-mannered. ${ }^{281}$ Charles, on the other hand, was depicted as a brave and successful soldier. Thus, counsel argued, even if François had stepped out of character and attempted to force Charles into the marriage, Charles would not have yielded unwillingly.

In further argument against Charles' claim of coercion, Nicole's advocates relied heavily on Venice, May 25, 1622 ${ }^{282}$ and Sánchez. Charles' reverential fear of his father was not invalidating. Indeed, Charles had a duty to obey his father's command to marry Nicole because the marriage was of sucli great importance to the family. If François used fear to secure Charles' performance of this duty, the fear inflicted was just and would not invalidate the marriage. Tlius counsel made the connection between the concepts of just fear and filial duty that Sánchez himself has left open. ${ }^{283}$

Nicole's lawyers also argued that even if Charles had been coerced into marriage, he subsequently consented of his own free will. Charles' own witnesses established that he and Nicole had lived together for twelve long years. This by itself was argued sufficient proof of subsequent consent. Buratto's sweeping dictum in Venice ${ }^{284}$ was cited for the proposition that the act of consummation by itself establishes consent. In addition, documents were imtroduced to show that Charles consistently referred to Nicole as his wife and as the Duchess of Lorraine. As the coup de grâce, Nicole's summarium included Cliarles' love letters to her from Besançon under the bold caption, "Letters of the Duke to the Duchess . . . about his marital affection."285 These acts establishing subsequent consent need not be accompanied by repetition of the Tridentine ceremony, counsel argued on the authority of Sánchez, because the alleged coercion was a secret impediment to the marriage in that it was unobserved by the witnesses to the wedding.

Nicole's summarium also cast doubt on the credibility of Cliarles' witnesses. Many were personal servants of Charles or his family.

280. Id. f.197.

281. Id. ff.213-14.

282. 2 Decisiones coram M. Buratto 308 (1637), discussed in text accompanying notes 192-95 supra.

283. See text accompanying notes $139-42$ supra.

284. See text accompanying note 195 supra.

285. Summarium pro D. Nicole ff.203r-207v. 
Charles' principal witness, Chalabré, was not only his chamberlain, but owed his appointment to Béatrice. Moreover, most of Charles' witnesses had testified in armed camps filled with his troops. Acute danger there awaited the witness who gave away anything to Nicole's case. One Lafontaine was crucified at Béatrice's command when he publicly doubted her marriage to Charles. ${ }^{286}$ Finally, Nicole's summarium showed that Charles' witnesses had been coached. In the language of this bar, Chalabre had been "instructed;" Charles' procurator had furnished him with a paper "to help his memory." nesses, according to their own admissions, had been shown in advance the articles on which they were to be examined.

\section{Evaluation}

On the whole, both sides were presented with competence, if not brilliance. Both sides were argunentative in their assumptions, their selection and arrangeinent of the evidence, their choice and employment of authority, and their choice of language. Like modern attorneys, counsel were acutely aware of the need to present the most favorable impression of their chent's case morally as well as' legally. Nicole's lawyers emphasized the facts as strongly as the law, while Charles' relied more heavily on legal theory alone. This difference was probably strategic, for there was far more in Nicole's plight to evoke the sympathy of the court than there was in Charles' situation.

The parties relied heavily on autliority. They used it to garland, emphasize, explaim facts. They used it as their raison d'être. The legal significance of every major assertion and of many minor assertions was estabhished by citation. Most writers tended to multiply citations to establish a single point. They tended to cite an authority once only, and relatively few cases and works were repeatedly emphasized. The effect was to show the range of authority rather than to develop much of it in depth. Direct quotation was not used except from Scripture or the text of statutes and decretals.

Decisions and treatises constituted the major authorities for the brief writers. The major court for these briefs was the Rota. Approximately 200 Rota opimions were cited approximately 600 times. Taken mainly from the last 50 years, these cases were the most modern, most persuasive, most vital authority invoked. When this case was in turn decided by the Rota, the court showed a marked preference for its own precedents over other forms of authority. Correctly anticipating this attitude of the tribunal, counsel for Nicole piled up the case law

286. Id. f.211r.

287. Id. f.212r. 
which favored her. Her superior legal position was, perhaps, reflected by the ratio of Rota precedents used by her counsel compared with Charles'-a ratio of almost two to one.

Rotal opinions made up much of the argument. But rotal opinions were themselves secondary to the law created by the commentators and now appealed by the advocates. Approximately 563 books, by 178 authors, were cited approximately 1,176 times. Quantitatively, the treatises were almost twice as important as the Rota itself, and quahitatively, in providing language and concepts, making distinctions, and spinning theory, the treatises were also more decisive for the lawyers than any other source of authority. If ever law was the law of the commentators, it was that presented by these advocates.

All of the treatises were in Latin, so that no partiality for a contemporary or a national tongue affected the choices made. Modern authors were not supposed to be favored "unless serious and commonly approved," 288 so that there was a built-in bias against very recent books which would not have yet been "approved" by custom. Otherwise, the prevailing tendency was to treat all the commentaries on an equal footing. A Spanish writer was as good as a Paduan, a fourteenth century text as helpful as a sixteenth century one. In the democratic world of jurisprudential reason, both national origin and age were effaced, and each authority was as good as any other. The Council of Trent overrode earher decisions and the canon law controlled the civil, but apart from this preference given the canons and later legislation, there was no sense of evolution in the law. In all its written manifestations the law was treated as a single, timeless whole, universal in its force. This judicial universe was taken as self-explanatory, and almost no use was made of works on philosophy, political theory, or listory.

The advocates argued principally by analogy. ${ }^{289}$ First, in the sense that every application of law to a new case is by analogy, they used this method. The case at bar was said to be like Seville or Venice, and the rules set down there were said to govern. This kind of argumentation can be described as argument by precedent, but the precedent becomes significant only when the analogical character of the case is grasped. Secondly, analogy was used in the sense of employing precedents from similar but dissimilar areas. Evidentiary standards for coercion were drawn from cases as unlike marriage annulments as those on tithes, parish priests, pensions, and rights of patronage. The principal field from which such more distant analogies were drawn was that of religious profession. In addition to Toul, November 7,

288. J. EMERIX, supra note 107, at 98.

289. See generally E. LeVI, AN Introduction to Legal Reasoning (1949). 
$1616,{ }^{200}$ whicl was the second most cited case of all, some 50 religious profession cases were cited by both sides.

Unlike the practice of modern advocates, lowever, the bar apparently had not yet developed methods for dealing with contrary authority. Cases that undermined a cited authority or asserted a proposition of law opposed to that which was being argued were neither distinguished, limited, nor disapproved; they were simply iguored. Thus Charles' lawyers made no attempt to distmguisli Venice from the imstant case, although distinctions were readily arguable. ${ }^{291}$ Similarly, Nicole's counsel did not deal with Seville and did not even cite Toul. This practice of ignoring contrary case authority was perlaps justifiable on the ground that the Rota did not follow the rules of individual cases as sucli but rather the stylus or line of decisions on a particular question; ${ }^{292}$ counsel sought to prove that their cases represented the preponderant view, and therefore, by implication, any contrary cases could be dismissed without inention as aberrations. On the other hand, no similar justification suggests itself for the practice of ignoring contrary commentaries.

\section{F. Judgment}

Sixteen years after Charles' wedding to Béatrice, 14 years after Rotal proceedings were imitiated, and five years after the trial had begun, Albergati announced the Rota's opinion in the case. ${ }^{203}$ "At the adinonition of the Supreme Pontiffs and at the suasion of other Princes," he began, Duke Henri II of Lorraine had promised to give his daughter Nicole to his nephew Charles in inarriage. His purpose was "to remove dissension" over the inheritance of the duchy. Charles and Nicole had given their consent. The Tridentine form was observed. Hence "the Lords liave judged that validity is established."

Almost 40 percent of the opimion was then devoted to the question of the form of the marriage ceremony which had not even been argued by Charles. The lack of a record by the parish priest did not prevent proof of the form by testimony. ${ }^{294}$ The casual or fortuitous presence of the parisl1 priest at the wedding was sufficient to meet the requirements of Trent. Moreover, the Bisliop was the priest of parisl priests, and the exemption of the chapel from his jurisdiction did not extend to the care of souls. On all these points Nicole's briefs were followed exactly.

290. 1 Decisiones coram M. Buratto 285 (1637).

291. See text following note 195 supra.

292. See text following note 107 supra.

293. Toul, January 15, 1653, 11 Decisionum recentiorum 396 (1716).

294. While the failure to mamtain the parish record book as required by the Council of Trent was a sin (see text accompanying note 119 supra), Albergati explained, it did not affect the capacity of the parties to contract a valid marriage. 
As to fear, proof of it failed through lack of good witnesses: "Almost all" were Charles' household people or servants or in his camp. Albergati was basically skeptical of the witnesses' testimony, and he piled up objections to it without bothering to qualify or distinguish Seville, June 18, 1607, ${ }^{295}$ and Coimbria, December 19, 1614, ${ }^{296}$ where servants had testified. Most of Charles' witnesses had failed to specify the circumstances of coercion, but had testified only that François had forced Charles. Such "generic proof" was imsufficient. Charles' witnesses were collectively criticized, but special consideration was given to the testimony of his "first witness," Chalabré, who alone had given the circumstances: He had been invalidly examined out of court; at best he had spoken not "of sure knowledge" but had provided only "signs for belief;" what lie had repeated as hearsay from Charles was inadmissible, because if Charles could not attack the marriage directly by testifying, ${ }^{297}$ his statements could not be received at second-hand.

Even if his witnesses were accepted, Albergati continued, Charles failed to show the kind of coercion that would nove a steady man. Suasion by parents was lawful. Reverential fear alone did not suffice. The threats alleged were "of no importance," given the mild character of François and the great-heartedness of Charles. None of the witnesses testified to coercion at the time of the second exchange of vows on June 6 before the Bishop of Toul. Circumstances concurred to prove positively that the consent exchanged was free. There was the mutual gaiety of the spouses at the betrothal; the repetition of the ceremony; the presence of blood relatives and other nobles; the active cooperation of the Bishop of Toul and Father Dominic; the subsequent consummation; the years of cohabitation; "the letters and other acts showing marital affection." All of the contentions pressed by Nicole's counsel on these points were accepted.

Albergati avoided any analysis of just fear and the duty to obey a parent by characterizing the acts of François as "licit and permitted persuasion." He avoided analysis of the requirements for ratification by finding that the marriage was valid from inception. The case he cited most was Buratto's decision affirming Cecilia's uncoerced marriage, Venice, May 25, 1622. ${ }^{298}$ He never inentioned the authority so favorable to Charles, the case of the Knight of Malta, Toul, November $7,1616 .^{299}$

That the marriage was an arranged one was emphasized, not dis-

295. Decisiones coram A. Ludovisio 387 (1622).

296. 1 Decisiones coram M. Buratto 116 (1637).

297. See text accompanying note 251 supra.

298. 2 Decisiones coram M. Buratto 308 (1637).

299. 1 Decisiones coram M. Buratto 285 (1637). 
guised, in Albergati's opinion. He acknowledged no difficulty in reconciling an arranged marriage with uncoerced consent. For him the line between persuasion and coercion was clear, and the social order required that the line be drawn. François had not overstepped it. Albergati had no occasion to ponder the need for or ineaning of marital affection at the time of the ceremony because Charles' advocates had not raised the issue. ${ }^{300}$ Charles' advocates had not raised the issue of form either yet, Albergati had devoted a substantial part of his opinion to that issue. The difference was that form was controllable by the Curia. Its exact observance was a matter which the curial courts oversaw with strictness. Marital affection, on the other hand, was not controllable by the Curia. If the inarriages of royalty and nobility were measured by the presence of marital affection in their inception, who knew how inany would survive? The balance between completely free choice by children of their mates and gross coercion by their parents had been struck in permittimg arrangeinent and persuasion. Albergati was not a inan to tip that balance by weighing marital affection in the scales.

Although this opinion was not a final judgment, ${ }^{301}$ a thorough rejection of the main contentions by one side and a complete acceptance of the inain contentions of the other must, nonetheless, have seemed formidible to overcome. This was especially true here since Albergati received Innocent X's permission to derogate froin a constitution of Urban VII ${ }^{302}$ that the vote in all cases was to be kept secret. The vote here, he announced, had been unanimous. ${ }^{303}$

Charles' counsel made one effort to save the day by asking for remissorial letters to re-examine his key witnesses. Chalabré, of course, was the man they wanted nost to rehabilitate. The request was turned down on January 12,1654 , as contrary to rotal practice after the record had been published and put in the hands of the parties. There was, Albergati observed, "strong danger of subornation" of the witnesses. Moreover, he noted, no witness had given specific evidence of the infliction of fear, and this deficiency of first-hand knowledge of particular acts could not be made up by new exainination. Matrimonial cases,

300. Although Charles' lawyers did present evidence of Charles' lack of affcction for Nicole prior to and immediately after the wedding (sce text accompanying notes 156-59 supra), this was for the purpose of showing that he did not inarry her willingly. Counsel did not argue that Charles' vows were invalid because unaccompauied by marital affection. See text following note 177 supra.

301. See text accompanying note 222 supra.

302. Urban VIII, Exponi nobis (Nov. 19, 1643), in 15 Bullarium 286 (1868). The reason for secrecy was to free the auditors from "importunate and uncivil" pressures on reargument. J. EMERIX, supra uote 107, at 127.

303. 3 E. CERCHIARI, supra note 93 , at $380-81$. 
he added without apparent irony, "needed swift determination."304

Charles then petitioned for a rehearing. On February 6, 1654, the auditors met to decide this issue. Albergati told them with little subtlety what his uncle had in mind: "The Most Holy One did not intend to favor one side more than the other, but he only reminded them that this case had been committed to the Rota fourteen years ago and had been in process there for a long time. For the rest, the Rota should proceed by observing what should be observed. His Holiness did not intend that the style of the tribunal be changed."305

Three days later, the petition was denied. Chalabré, "was inade strongly suspect since he deposes with too great partisanship and of his own belief." ${ }^{306}$ The other witnesses on coercion were unconvincing. The positive evidence of free consent was great. With this short review of the facts, the Lords "stood unanimously on what has been decided." 307 Along with the citation of canons, Albergati now invoked the commandment of the Lord, "What God hath joined together, let no man put asunder." 308

Judgment was issued the following month on March 23, 1654, in accordance with the opimion. The decision now became executive. Silence was imposed on Charles; that is, further judicial recourse was denied to him. In the same year, the judgment was published in the vernacular in Nancy.

\section{V \\ EPILOGUE}

One month before the rotal judgment became executive in 1654, Charles was arrested by the Spamish in Brussels where he had been a general in the Emperor's employ and transported to the Alcazar in Toledo where he was forced to remam. ${ }^{309}$ He was arrested because the Spanish had become uncertain of his loyalty. Yet Charles had always been a restless ally, and the Spanish were so far froin having any concrete case against him that he was accused of no crime. He was treated with the cold civility used for important political liostages. It seems probable that the arrest was triggered by the fear that Charles, angry and frustrated by the final result in the Rota after 17 years of insisting that Béatrice was his wife, would go over to the Protestants. Detention in Spain afforded him time to reconcile himself to the voice

304. 11 Decisionum recentiorum 444 (1716).

305. 3 E. Cerchiarr, supra note 93 , at 384.

306. 11 Decisionum recentiorum 453 (1716).

307. Id.

308. Matthew 19:6.

309. See 4 A. CALmET, supra note 2 , cols. 485-98. 
of the Church. That Nicolas-François arranged the arrest has been suspected, is plausible, but has not been proved..$^{\mathbf{3 1 0}}$

Nicole, still in Paris, worked for his release, and although her efforts were unavailing, her concern was sufficient to touch her depressed and deserted husband. Disillusioned with brother Nicolas-François, Charles, on February 28, 1655, gave Nicole all his authority over Lorraine and the troops of Lorraine. ${ }^{311}$ Froin this point on his relation to her was one of trust, if not of love.

On January 14, 1657, he wrote her from Toledo, "I have so many evidences of the good things you constantly do for me that I forget the meinory of inyself in wishing for a chance where I could make you know that nothing could be more yours than me."312 This was the last communication between the two spouses, if indeed his letter ever reached her. Nicole died in Paris on February 20, aged 48, married 36 years, separated 23 of thein. ${ }^{313}$

After Nicole's death, Béatrice expected Charles to marry her. Their correspondence since his arrest had not been great, but he still wrote tenderly to their daughter Anne, and as late as 1654 he still had hoped for a "remedy in Roine." 314 On Nicole's death, Béatrice sent an emissary, one Pelletier, to Spain to arrange the marriage, or what she referred to as the "ratification of my marriage." 315 At 40, she wanted establislied ecclesiastically what slie liad always held to be the truth, that she was Cliarles' wife. "I want to be before the world," she informed Pelletier, "what His Highness knows very well in his conscience we are before God."316

Charles, however, had cooled. Partly it was chagrin at Béatrice's failure to be energetic in getting him out of Spanish captivity. Partly it was irritation at her "extravagance" while he led a confined existence and her failure to leave the court at Brussels where Charles knew well she was exposed to teinptations. The "most innocent things at Brussels," Béatrice observed, "are reported as criminal to H.H." ${ }^{317}$ Partly it was remorse and the new feelings he had developed for Nicole. Finally, he had not seen Béatrice for three years, and when he had last seen her, their feelings had scarcely been friendly. ${ }^{318}$

310. 3 id. col. 491.

311. Parisot, Introduction to Robert, Documents inédits sur la captivité de Charles IV a Tolède (1654-1659), in 60 SocIETE, 338 (1910).

312. Id. at 391-92.

313. Id. at 351 .

314. P. MARECHAX, supra note 21 , at 243.

315. $1 d$. at 257.

316. Id. at 262 .

317. Id. at 258.

318. See text accompanying nóte 240 supra. 
Charles stalled. A marriage with her, he argued, might irritate his brother, alienate France, and jeopardize his release. There was no need to act precipitously. Later, he argued, he needed a dispensation from Rome to wed her. The canomical impediment he now imvoked by implication was adultery. ${ }^{319}$

Béatrice's response was predictable. She was, she wrote Pelletier, "becoming crazy" with his excuses. She "needed the patience of Job" to endure them. She was "filled with shame" at "His Highness taking no action since p. N's death or at least since he knew of it." She encouraged Pelletier to continue his efforts: "May God do all for His glory and our salvation and assist you in all things in a cause which is as just as the one you undertake for me-the ratification of my marriage that there cannot be better before God." 320

Charles was finally released from captivity as part of a general European peace settlement made by the Treaty of the Pyrennees in 1659. In eclipse, he spent his time at the court of Louis XIV in what may be imagined as boredoin, intrigue, and amorous dalliance.

Béatrice continued in pursuit. In 1661 she came to Bar in search of Charles. Nicolas-François noted her arrival and did not relax his vigilance. Not now would he let happen what he had tried for over 20 years to stop. He wrote the Pope, now Alexander VII, as he had written the General of the Jesuits back in 1641. The Pope, he advised, should not consent to the dispensation Charles would need to marry. ${ }^{321}$

Nicolas-François was probably alarmed without cause. Charles' advocate in the Rota, Celio Piccolomini, was now Nuncio to France. Charles sent a Jesuit to discuss the dispensation with him, and on July 1,1661 , Piccolomini wrote that there would be great difficulties in getting it. Union with Béatrice would be a fresh scandal for the Cluurch. Exercise of the papal prerogative to wiave the barrier of adultery could not be expected. ${ }^{322}$ This letter from an old advocate had the marks of what an old client might have asked him to provide. What better way to rout Béatrice, for Charles himself was now in pursuit of another, Marie-Anne Pajot.

Louis XIV saved Charles from another unsuitable marriage by popping Mlle. Pajot into a convent. ${ }^{323}$ But Charles continued in his search for youth and beauty. In 1664 at Mircourt in Lorraine lie betrothed himself to a new girl, Isabella, Countess de Ludre.

319. Decretal law forbade an adulterer to marry his paramour. See X 4.7.2;

$X$ 4.7.5. The Pope, however, could grant dispensation from this impediment.

320. P. MARECHAL, supra note 21 , at 258-61.

321. Bonnard, supra note 2, 71 SocIETE 270.

322. Id. at 271.

323. Id. at 265 . 
Béatrice felt badly enough about this project to go to Mircourt to let Isabella's mother know that Charles was already married to her. ${ }^{324}$ This trip was the last expedition of her life. Returning to Besançon, she fell ill, and her end was predicted. She wrote Charles, asking as her dying wish that he marry her and legitimate the children. Assured that the tie would not last long, responsive perhaps to the memories of their great passion, pleased to have a lawful male heir, Charles agreed, but without inconveniencing himself. He sent a proxy. The Archbishop of Besançon dispensed the couple front the impediment of adultery. On May 20, 1664, Charles and Béatrice were married.

Béatrice died two weeks later. Her will, executed just after the proxy wedding, spoke of Charles as "my very dear husband." She returned the diamond he had given her on that other wedding day of theirs in 1637.325 In 1665, Charles, aged 62, married Marie-Louise d'Apreniont, aged $13 . .^{326}$

Charles V, son of Nicolas-François and Claude, ultimately inherited the duchy of Lorraine. ${ }^{327} \mathrm{He}$ is fittingly noted in the history of Pont-à Mousson as its most illustrious pupil and to have been "the glorious conqueror of the Turks, the greatest beyond question of the descendants of Gérard of Alsace."”328

\section{CONCLUSION}

Accommodation of conipeting values is no doubt the principal characteristic of legal systems. However high a priority is given one value, if its presentation is entrusted to the law it is certain to be compromised. The legal process, to be a process at all, will take other values into account. Enthusiasts eager to make society turn on their insights, dictators interested in instant compliance with their will, are well advised to avoid the law. Fron one point of view, the canon law on naarriage was meant to teach a single lesson, imcorporate a single value. But the tensions of the canonical process in a marriage case reflected the multiple values which the system actually accommodated.

324. 3 A. CALMET, supra note 2, col. 609.

325. P. MARECHAL, supra note 21 , at 420 .

326. Bonnard, supra note 2, 71 SocIETE 265.

327. It is not clear why Charles-Henri, son of Charles and Béatrice, did not inherit the duchy instead. Perhaps the 1664 wedding did not in fact legitimate Charles-Henri as his parents had hoped (see text following note 324 supra), since papal dispensation had not been obtained (see note 119 supra and accompanying text). Perhaps the fact that Charles had at once time abdicated his title (see text accompanying note 28 supra) made his heirs inelligible to succeed him. Or perhaps Charles $V$ simply proclaimed himself Duke at a time when Charles-Henri was without the means to challenge him. Cf. text accornpanying note 85 supra.

328. 4 Les etablissements des Jesutes en France depuis QuATRe siecles col. 118 (P. Delattre ed. 1956). 
Indissolubility of marriage was no doubt the raison d'être of the system. If this ideal had not been a value to be preserved, the whole canonical enterprise would have lacked focus. But the procedural options offered to the participants revealed how many other interests besides indissolubility were being balanced.

The most obvious deterrent to a second marriage in the lifetime of an existing spouse was a prosecution for bigamy. Urban VII, author of Magnum in Christo, was not unaware of his option to bring such a prosecution agamst Charles of Lorraine. Yet he preferred to let other values have play, and his successor even permitted the possible criminal bigamist to bring his civil suit to test the validity of the first marriage. Just as a criminal antitrust case may be too heavyhanded a way to act against a major business proceeding with the advice of counsel, so criminal bigamy was too crude a weapon to use against a well-counselled duke. The compromise was paradigmatic of the system's moderation.

The familiar equity principle of clean hands, barring from the court a petitioner guilty of misconduct with respect to the subject matter of his suit, had been developed by the canomists themselves and apphed by them in matrimonial litigation where the object of a suit was judicial separation. An adulterer could not, on the grounds of his spouse's adultery, obtain a separation; his own guilt kept him from judicial relief. Little legal imagination was needed to have developed an analogous doctrine for annulment. But the system went no further than insisting that Charles be separated from Béatrice before lie would be admitted to sue. Any other rule would have meant that the papal courts would have had very hittle marriage business to consider. An absolute bar brought about by an adulterous union would have produced a lack of flexibility which the managers of the system sought to avoid.

In the same spirit, the statute of himitations set by $A d$ id was overridden by the commentators and the practice-so overridden that it was not even argued to the Rota in Charles' case, although it stood on the books as good decretal law. The lack of a statute of limitations evidently produced the evils such statutes are designed to prevent: ascertainment of what had happened at the time of consent became extremely difficult; the chief actors, François and Henri II, were dead; perjury was easy. At the same time, Nicole's expectations were cruelly sliaken by Charles' challenge to the marriage some 25 years after she had participated in two public wedding ceremonies with him. The absence of a cut-off on litigation in the canonical system meant that no one could ever be completely assured of their marital status. These evils, evident enough to the perspicacious lawyers wlio ran the system, 
were accepted because it was thought more essential to have flexibility. An escape hatch, however small, could be glimpsed in any miserable marriage.

The welcoming of long-postponed hitigation and the postponing of litigation which had begun were of a piece. From the date of Charles' marriage to Béatrice to the date of final judgment, 19 years elapsed; from the date of Nicole's complaint to the Pope, 15 years; from the date of Charles' filing suit in the Rota, 7 years. The case was finally decided only after leading figures of the House of Lorraine lrad pleaded with the Pope to decide it, and after the Pope had obtained Cliarles' specific agreement to abide by the Rota's judgment. None of this procedure was consistent with a desire to vindicate as promptly as possible the indissolubility of marriage. In effect, the system substituted delay for compromise.

Compromise is the normal achievement of a judicial system, but marriage in these cases could not be formally compromised. On the narrow issue, Is $A$ inarried to $B$ ?, the answer had to be either yes or no. Doctrine permitted no surrender of half a spouse's claims. Not able to produce the normal result of litigation directly, the system substituted delay. In delay eacli person had the psychological satisfaction of believing that his rights would eventually be vimdicated. While there could be only one winner, two could have hope of winning. In delay no one was forced to an absolute and irretrievable rupture with the Church. In delay there was the possibility that one person might die, that passion might cool, that reconciliation could be accomplished. Accepting delay as a method, the managers of the system tacitly acknowledged that the indissolubility of marriage could to some extent be subordinated to other values.

The system was in tension, looking backwards and looking forward. As a judicial system, it was mcurably historical. It sought to determine whether consent had been given to marriage, as a judge will seek to ascertain if a contract was made or a tort committed. Historical method is used to determine who owns a piece of land, who owes a debt, who had cominitted a crime; so the judicial system used past facts to determine who were married. Yet as a system charged with affecting the future lives of two persons, it could not escape some orientation to the future. The more it looked to the future, even if ouly by delaying judgment, the more administrative discretion and pastoral concern predominated over strictly historical interest in what had once happened.

If indissolubility was to be protected it was because marital consent liad actually been exclianged by the parties. The rules of evidence had as conscious motivation that the judge's decision rest on the truth. 
The courts were interested in what had happened. Mere recital of a legal fiction would not suffice to obtain dissolution of a marriage. In California, before the new divorce law was enacted, ${ }^{329}$ an uncontested divorce could be obtained in five minutes by the petitioner repeating a formula charging the respondent with extreme cruelty. ${ }^{330}$ The canonical procedure eschewed ritual of this kind. Clumsily, haltingly, earnestly, the system sought the actual circumstances of consent.

Yet at the same time the realities of the case were submerged by the focus and formulae of testimony and argument. Charles' lawyers argued that he had never freely consented to Nicole. Nicole's lawyers argued that Charles had consented from the beginning. The argument for Charles looked past the twelve-year life of the couple together. The argument for Nicole iguored the circumstances of Charles' position at the age of 18. The effort of the lawyers to fit the facts to the governing law gave the court a choice between two contrived accounts of a palpable unreahity.

Once submerged, the fresh facts were surrounded with citations froin old cases and established commentaries. A plane of abstraction was created where the events of the case at bar were interwoven with old precedents. An intricate patterning of fact and citation was executed with the greatest artistry by the teams of lawyers employed to present tapestries of argument to the Rota. So much time, care, energy, and thought were devoted to the discovery and proper arrangement of precedent that the lawyers gave little attention to the unique factual constellation of the case. The system's interest in "the truth"- - Had consent to marriage been given?-was accommodated to the educational interests of the system.

The educational impact of the system was, like that of other legal systems, chiefly on its active participants-the lawyers, judges, and professors. The briefs and opmions interlaced with citations created a universe of intelligible discourse. Coral-like, the cases gave the law a rational structure, into which the precedents initiated the managers of the system. The legal system provided its active participants with traiming in the art of analysis, the use of abstractions, the savoring of distimctions. It taught them to probe human motivation, question human credibility, and doubt liuman love. It gave them practice in affirming principle and in tempering principle. It forned the men who were the managers of the Curia so that they would be discreet, dispassionate, unillusioned, determined, patient, as self-limited as accountants, as self-approved as diplomats.

329. CaL. Civ. Code $\S \S 4500-21$ (West Supp. 1970).

330. See Kay, A Family Court: The California Proposal, 56 CalIr. L. Rev. 1205, 1218-19 (1968). 
Those who participated passively as parties-Nicole, Charles, and Béatrice-received a much more uneven education. They had entered the system by accident. The system did not adjust to their capacities for instruction. The legal arguments, of course, escaped thein entirely. Nothing suggests that Charles or Nicole ever read the briefs, which their lawyers addressed to one another and the court, or the opinion, which the court addressed to the lawyers. What the parties learned to value was the end result, the authoritative judgment of the court which bound them or loosed them. The education iniparted was a lesson not so much in the indissolubility of a inarriage, which might or might not be dissolved, as in the power of the papacy to determine their status and enforce its decrees. Béatrice was no more convinced by the Rota's decision that she was not truly married than Nicole needed that decision to assure her that she was Charles' wife; and Charles returned, at long distance, to Nicole, not because he had lost his case in the Rota, but because he had lost interest in Béatrice. For the bulk of Charles and Nicole's married life the system did nothing to preserve their marriage as an effective symbol of the union of Christ and the Church. Setting out to defend a symbol of love, the active participants in the system seemed to make the commonest of hunuan mistakes, to forget the purpose of their endeavor. Absorbed in the necessary operations of a sophisticated legal enterprise, they did not stop to ask how the education which they imparted to each other and the parties related to the reasons for defending the symbol.

An educational mission which was directed to upholding a symbol of love in the community and educational methods which instructed the participants in legal technique and the use of power; significance to hitigants which was prospective and formal focus which centered on the past; concentrated concern with individual cases and subordination of the individuals to the symbolic value of their acts; commitment to an absolute choice between two exclusive alternatives and incapacity to reach the terminal poimt of choice; judicial form dominated by the paternal and pohtical features of the organization in which the form was set; dependence on principle for raison d'être and responsiveness to policy judgments which halted the sweep of primciple; affirmation of what transcended time and a subservience to social norms; responsibility for the symbolism of love and a forgetfulness of purpose such that love was lost - these were the characteristics of the canomical curial system as it operated im the case of Charles and Nicole, and as it was to operate for several succeeding centuries. 


\section{California Law Review}

VoL. 58

No. 3

\section{BOARD OF EDITORS 1969-70}

Editor-in-Chief

H. LEE VAN BoveN

Managing

THORNTON E. RoBISON

WALTER L. CARPENETI

A. Terry Slocum

Notes \& Comments

PAUl HoEber

PETER N. SMMON

JAMES W. BROWN MARY LU EVERETT ROBERT W. JINKS Marietta Poerio ERIC R. RoOst WENDY WILLIAMS
Articles

Derek A. Westen

GlenN C. Frese

VINCENT L. RICCI

Book Reviews

ROBERT G. WERNER

Executive Editor

JEFFREY R. FREUND
Research

PAUL HoEber

Ned A. FINe

JOHN GRATWER

LEONARD MENTZER

TIMOTHY TOWER

Special Projects

FrankIIN R. GARFIELD

KOREY A. MANDEL

Administrative Aide

SUSAN G. VeGA 


\section{California Law Review}

VOL. 58

MAY 1970

No. 3

BOARD OF EDITORS 1970-71

Editor-in-Chief

JOSEPH T. KIEFER

Managing

ROBERT D. EVANS

DARVISH M. KORDESTANI

Michaze George KozAK

Notes \& Comments

Articles
WIILIAM F. COOK
STEVEN FINELI
MARIA TANKENSON
Supreme Court Editor
GREGORY J. HOBBS, JR.
Executive Editor

PAUL W. GLENN

Michael L. MEYeRS

BRuCe S. Ross

KENT A. RUSSELL

JAMIES TOLEDANO

MERRICK JoHN BOEB

William M. Chamberlain

DiANe D. EAmes

ROBERT ERICSON

JUDITH G. KLEINBERG

WiLliam Billingslea, $J_{R}$.
Research
G. KIP EDWARDS

DAVID R. ANDREWS

Charles H. HuRd

Douglas M. LAURICE

ROBERT LEVY

Book Reviews

J. Michael BrenNaN

MARY DUNLAP
Associate Editors

Gene Harter

Ellyn A. Hershman

ROBIN MEADOW

Douglas Alan Oglesby

LAWRENCE B. ORDOWER
Richard L. Perez

Peter E. Sheehan

Margaret SHeRWOOd

MichaEL B. SimON

ROBERT D. StrATMORE

Administrative Aide

Susan G. Vega 